\title{
Structure-activity relationships of anthraquinone derivatives derived from bromaminic acid as inhibitors of ectonucleoside triphosphate diphosphohydrolases (E-NTPDases)
}

\author{
Younis Baqi • Stefanie Weyler • Jamshed Iqbal • \\ Herbert Zimmermann • Christa E. Müller
}

Received: 13 January 2008 / Accepted: 10 April 2008 / Published online: 5 June 2008

(C) Springer Science + Business Media B.V. 2008

\begin{abstract}
Reactive blue 2 (RB-2) had been characterized as a relatively potent ectonucleoside triphosphate diphosphohydrolase (E-NTPDase) inhibitor with some selectivity for NTPDase3. In search for the pharmacophore and to analyze structure-activity relationships we synthesized a series of truncated derivatives and analogs of RB-2, including 1-amino2-sulfo-4-ar(alk)ylaminoanthraquinones, 1-amino-2-methyl-4arylaminoanthraquinones, 1-amino-4-bromoanthraquinone 2 -sulfonic acid esters and sulfonamides, and bis-(1-amino4-bromoanthraquinone) sulfonamides, and investigated them in preparations of rat NTPDase1, 2, and 3 using a capillary electrophoresis assay. Several 1-amino-2-sulfo-4-ar(alk)ylaminoanthraquinone derivatives inhibited E-NTPDases in a concentration-dependent manner. The 2-sulfonate group was found to be required for inhibitory activity, since 2methyl-substituted derivatives were inactive. 1-Amino-2-sulfo4-p-chloroanilinoanthraquinone (18) was identified as a nonselective competitive blocker of NTPDases1, 2, and 3 ( $\left.\mathrm{K}_{\mathrm{i}} 16-18 \mu \mathrm{M}\right)$, while 1-amino-2-sulfo-4-(2-naphthylamino) anthraquinone (21) was a potent inhibitor with preference for NTPDase1 $\left(\mathrm{K}_{\mathrm{i}} 0.328 \mu \mathrm{M}\right)$ and NTPDase $3\left(\mathrm{~K}_{\mathrm{i}} 2.22 \mu \mathrm{M}\right)$. Its isomer, 1-amino-2-sulfo-4-(1-naphthylamino)anthraquinone (20), was a potent and selective inhibitor of rat NTPDase3 $\left(\mathrm{K}_{\mathrm{i}} 1.5 \mu \mathrm{M}\right)$.
\end{abstract}

\footnotetext{
Y. Baqi $\cdot$ S. Weyler $\cdot$ J. Iqbal $\cdot$ C. E. Müller $(\triangle)$

Pharmaceutical Institute, Pharmaceutical Sciences Bonn (PSB), Pharmaceutical Chemistry I, University of Bonn,

An der Immenburg 4,

53121 Bonn, Germany

e-mail: christa.mueller@uni-bonn.de

H. Zimmermann

AK Neurochemie,

Biozentrum der J.W. Goethe-Universität Frankfurt,

Frankfurt am Main, Germany
}

Keywords Anthraquinone - E-NTPDase - Inhibitor · Reactive blue 2 . Synthesis

$\begin{array}{ll}\begin{array}{l}\text { Abbreviations } \\ \text { ARL 67156 }\end{array} & N^{6} \text {-diethyl- } \beta, \gamma \text {-dibromomethylene-ATP } \\ \text { CE } & \begin{array}{l}\text { capillary electrophoresis } \\ \text { dimethyl sulfoxide }\end{array} \\ \text { DMSO } & \text { electron impact } \\ \text { EI } & \text { electrospray ionization } \\ \text { ESI } & \text {-[2-hydroxyethyl]piperazine- } N^{\prime} \text { - } \\ \text { HEPES } & \text {-ethanesulfonic acid } \\ \text { high-performance liquid chromatography } & \text { high-resolution mass spectrometry } \\ \text { HPLC } & \text { nuclear magnetic resonance } \\ \text { HRMS } & \text { (ecto)-nucleoside 5'-triphosphate } \\ \text { NMR } & \text { diphosphohydrolase } \\ \text { (E)-NTPDasidoxal phosphate-6-azophenyl-2', } \\ \text { PPADS } & \begin{array}{l}\text { '-disulfonic acid } \\ \text { reactive blue } 2\end{array} \\ \text { RB-2 } & \text { structure-activity relationship(s) }\end{array}$

\section{Introduction}

Extracellular nucleotides such as ATP, adenosine diphosphate (ADP), uridine triphosphate (UTP), and uridine diphosphate (UDP) act as extracellular signaling molecules in virtually all tissues and organs [1]. Especially ATP is involved in a variety of physiological and pathological functions in the body, e.g., as a neurotransmitter and neuromodulator in the central and peripheral nervous system, as a key messenger in nociception, as a tumor-inhibiting agent, in the control of secretion from a variety of endocrine glands, in the modulation of platelet aggregation by ADP, in chloride 
transport in the airway epithelia, in renal function, in bone and cartilage disease, and as a proinflammatory agent in the immune system [2, 3]. Extracellular nucleotides are efficiently inactivated by surface-located enzymes which sequentially hydrolyze the phosphate groups eventually resulting in the formation of the respective nucleoside and inorganic phosphate [4]. Nucleoside 5'-triphosphates and 5'-diphosphates may be hydrolyzed by members of the E-NTPDase (ectonucleoside triphosphate diphosphohydrolase) family, the ENPP (ectonucleotide pyrophosphatase/phosphodiesterase) family, and by alkaline phosphatases. Nucleoside 5 '-monophosphates are subject to hydrolysis by ecto-5'-nucleotidase and also by alkaline phosphatases [5]. Members of the various ectonucleotidase families reveal overlapping substrate specificity and tissue distribution whose functional significance needs to be further elucidated [4].

E-NTPDases comprise eight members, four of which have two plasma membrane-spanning domains with an active site facing the extracellular milieu [4-6], namely, NTPDase1 (CD39), NTPDase2 (CD39L1), NTPDase3 (CD39L3), and NTPDase8 [7, 8]. In contrast, NTPDase4, 5, 6, and 7 are intracellular membranes proteins. Even though NTPDases5 and 6 may be present at the surface of the plasma membrane and secreted as soluble enzymes following a proteolytic cleavage, their high $\mathrm{K}_{\mathrm{m}}$ values and low specific activities [9] make it unlikely that these enzymes regulate P2 receptor signaling. NTPDases share five highly conserved sequence domains (apyrase conserved regions) that are presumably of major relevance for their catalytic activity [10]. They contain the actin-HSP 70 -hexokinase $\beta$ - and $\gamma$-phosphate binding motif $[11,12]$.

Members of the E-NTPDase family can hydrolyze nucleoside 5'-triphosphates and nucleoside 5'-diphosphates albeit with varying preference for the individual type of nucleotide $[10,11]$. NTPDase1 (CD39, ectoapyrase, ecto-ATP diphosphohydrolase) hydrolyzes ATP and ADP at a molecular ratio of about 1:0.5 to 1:0.9 [13]. In contrast, NTPDase2 has a strong preference for ATP with molecular ratios of ATP:ADP of 1:0.03 or less. NTPDase3 is a functional intermediate and reveals a molecular ratio of ATP:ADP of approximately 1:0.3. The activity of all three types of ectonucleotidases depends on millimolar concentrations of divalent cations such as $\mathrm{Ca}^{2+}$ or $\mathrm{Mg}^{2+}[11,13,14]$. The enzymes hydrolyze not only ATP or ADP but have broad substrate specificity towards purine and pyrimidine nucleotides.

The analysis of nucleotide release requires the availability of inhibitors of ectonucleotidases that should ideally have no effect on $\mathrm{P} 2$ receptor activation [6]. It has been demonstrated that stable analogs of ATP can elicit tissue contractions up to 100 times more effectively than ATP. This suggests that the effects of exogenously applied ATP on P2 receptors are limited by its enzymatic degradation. Inhibitors of ectonucleotidases could thus serve as drugs that increase the life- time of extracellular ATP (or ADP, UTP, or UDP) in situ. They could act in a site- and event-specific manner since they would only have an effect when nucleotides are present.

NTPDase1 is the major physiological E-NTPDase member showing a nearly ubiquitous tissue distribution. It is constitutively expressed in microvascular endothelium and certain immune cells and plays an important role in thromboregulation and immune function [15]. The distribution of NTPDase2 appears to be more restricted. NTPDase2 has been detected on blood vessels [16], cultured brain astrocytes [17], and on certain neuronal progenitor [18] and cancer cells $[19,20]$. In contrast, NTPDase 3 is expressed in the brain exclusively in neurons, with a predominantly axonal localization. Its colocalization with hypocretin-1/orexin-A indicates that it may be involved in the modulation of feeding, the sleep-wake cycle, or other behavioral components [21]. NTPDase 3 has also been reported to be involved in auditory neurotransmission since it is highly expressed in the cochlea [22].

Potent and selective inhibitors for the individual NTPDase isoenzymes are required as pharmacological tools to investigate the (patho)physiological roles of NTPDases. Furthermore, such compounds are required to study their potential as novel drugs, e.g., for the treatment of cancer, as immunomodulatory agents, and for the treatment of cardiovascular or central nervous system disorders. So far only few classes of NTPDase inhibitors have been described [23] (Fig. 1).

These include nucleotide derivatives and analogs, mainly derived from ATP. Until recently, the only compound that has been shown to effectively inhibit the hydrolysis of ATP in a variety of tissues (albeit with moderate potency) without significantly acting on P2 receptors was the structural analog of ATP, ARL 67156 (1, FPL 67156) $\left(N^{6}\right.$-diethyl- $\beta$, $\gamma$-dibromomethylene-ATP) [24-26]. However, ARL 67156 was recently found to be nearly inactive at rat, mouse, and human NTPDase2 [27, 28]. Although $\mathbf{1}$ is stable versus ecto-alkaline phosphatases and E-NTPDases, it might be hydrolyzed by E-NPPs, which directly attack the oxygen bridge between the $\alpha$ - and $\beta$-phosphorus atom of ATP and related compounds. However, Sévigny and colleagues showed that human NPP1 and NPP3 were unable to hydrolyze ARL 67156 [28]. 8-Thioether-ATP derivatives, found inactive at $\mathrm{P} 2 \mathrm{Y}$ and $\mathrm{P} 2 \mathrm{X}$ receptors, and stable to NTPDase hydrolysis, have also been described as NTPDase inhibitors. 8-Butylthioadenosine-5'-triphosphate (compound 2) acts as a competitive inhibitor of ATP with an estimated $\mathrm{K}_{\mathrm{i}}$ value of $10 \mu \mathrm{M}$ at NTPDase from bovine spleen [29]. Although the compound appears to be stable against NTPDases, it is likely to be hydrolyzed by the ubiquitously present ectoalkaline phosphatases which accept a very broad variety of substrates. Very recently, we have developed metabolically stable, uncharged nucleotide mimetics derived 
<smiles>CCN(CC)c1ncnc2c1ncn2[C@@H]1O[C@H](COP(=O)([O-])OP(=O)([O-])C(Br)(Br)P(=O)([O-])[O-])[C@@H](O)[C@H]1O</smiles>

1 ARL67156<smiles>CCOP(=O)(Cc1ccc(NC(=O)CNC(=O)C2OC3C(=O)NC(=O)C=CN3C2O)cc1)OCC</smiles><smiles>CCCCSc1nc2c(N)ncnc2n1C1OC2OC1C(OP(=O)([O-])OP(=O)([O-])OP(=O)([O-])[O-])C(O)C2O</smiles>

2 8-Butylthio-ATP<smiles>Cc1ccc(C(=O)Nc2ccc(S(=O)(=O)O)c3cc(S(=O)(=O)O[Na])cc(S(=O)(=O)O[Na])c23)cc1NC(=O)c1cccc(NC(=O)Nc2cccc(C(=O)Nc3cc(C(=O)Nc4cc(S(=O)(=O)O)ccc4C)ccc3S(C)(=O)=O)c2)c1</smiles>

4 Suramin<smiles>CS(=O)(=O)c1ccc(Nc2nc(Cl)nc(Nc3ccc(Nc4cc(S(=O)(=O)O)c(N)c5c4C(=O)c4ccccc4C5=O)c(S(C)(=O)=O)c3)n2)cc1</smiles>

5 Reactive Blue 2 (RB-2)<smiles>Cc1cc(N=Nc2ccc(S(C)(=O)=O)cc2S(=O)(=O)O)c(COP(=O)(O)O[Na])c(C=O)c1O</smiles>

6 PPADS

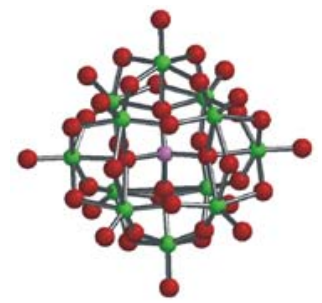

$\left[\mathrm{TiW}_{11} \mathrm{CoO}_{40}\right]^{8-}$

7 POM-4

Fig. 1 Structures of NTPDase inhibitors

from uridine 5'-carboxylate and identified PSB-6426 (3) as a selective inhibitor of human NTPDase2 [30].

Besides inhibitors derived from nucleotides, non-nucleotide NTPDase inhibitors have been described. These include suramin (4) and related compounds [13, 31-33], sulfonate dyes such as reactive blue 2 (RB-2, 5) [34-37], and PPADS (6, pyridoxal phosphate-6-azophenyl-2',4'-disulfonic acid) $[13,38,39]$, which can all attenuate the hydrolysis of ATP. However, all of these compounds are nonselective, as they are also potent antagonists at $\mathrm{P} 2$ receptors. We recently identified a novel class of NTPDase inhibitors, the polyoxometalates (POMs), which are inorganic anionic metal complexes, e.g., POM-4 (7) [40]. These compounds have turned out to be useful pharmacological tools [41-43]. However, they have high molecular weights, bear several negative charges, and are not drug-like molecules.

The present study was aimed at identifying the pharmacophore of RB-2 for inhibiting NTPDases and at investigating the structure-activity relationships of truncated RB-2 derivatives. Since RB-2 shows some selectivity for rat NTPDase $3\left(\mathrm{~K}_{\mathrm{i}} 1.10 \mu \mathrm{M}\right.$, approximately 20 -fold selectivity vs NTPDase1 and 2) [27, 44], we expected that this strategy might lead to the identification of an NTPDase3-selective inhibitor.

\section{Results and discussion}

Syntheses

The 1-amino-4-anilino-2-sulfoanthraquinone derivatives 11-19 were synthesized as recently described by combinatorial parallel synthesis using the Ullmann coupling reaction [45]. The new compounds 20-22 were obtained by two different methods. The 1-naphthyl (20) and the 3, 4-dimethoxyphenyl derivative (22) were synthesized by the classic Ullmann reaction from bromaminic acid (8) and 1-naphthylamine, or 3,4-dimethoxyphenethylamine, respec- 
tively, in water in the presence of potassium carbonate and copper sulfate at $100-105^{\circ} \mathrm{C}$ (see Fig. 2). The 2-naphthyl derivative (21) was obtained by a new microwave-catalyzed Ullmann reaction in phosphate buffer using elemental copper as a catalyst [46] within only 5 min reaction time (Fig. 2). The 1-amino-2-methyl-4-arylaminoanthraquinone derivatives 23-26 were obtained by solvent-free reaction of 1-amino-4-bromo-2-methylanthraquinone (9) with the appropriate arylamine derivative in the presence of copper acetate and potassium acetate at $110^{\circ} \mathrm{C}$ for $5-24 \mathrm{~h}$ according to a procedure described by Harris et al. [47] (see Fig. 2).

Anthraquinone sulfonic acid esters $\mathbf{2 7 - 3 0}$ and sulfonamides (31-33) were obtained by chlorination of bromaminic acid (8) with phosphorus pentachloride in phosphorus oxychloride to yield the sulfonic acid chloride 10 as a reactive intermediate, which was subsequently treated with the appropriate alcohol or phenol, or ar(alkyl) amine under basic conditions (Fig. 3). When $p$-ethoxy- or $o$-methoxy-substituted aniline was used for the condensation with 10, the desired simple sulfonamide derivatives were not obtained. Mass spectral and nuclear magnetic resonance (NMR) analysis revealed that bissulfonamides 34 and $\mathbf{3 5}$ had formed instead, although the anilines had been present in the reaction mixtures in excess. The explanation may be an increased nucleophilicity of the aniline nitrogen atom due to the positive mesomeric effects of the substituents (o-methoxy, $p$-ethoxy).

Solubility and stability of selected anthraquinone derivatives

It was observed that some anthraquinone sulfonic acid sodium salts, which were initially well soluble in water, formed precipitates during the testing. One explanation may be that the high salt concentrations in the buffer solutions, e.g., the presence of calcium ions, which may form hardly soluble calcium sulfonates, reduced their solubility. Howev- er, precipitation might also be due to another chemical reaction. Therefore, selected 1-amino-4-phenylamino-2sulfoanthraquinone derivatives $(12,15,17,18)$ bearing different substituents on the phenyl ring (o-methyl, $o, p$ dimethyl, $o$-ethoxy, and $p$-chloro residues) were investigated for their stability under the test conditions. Aqueous solutions $(10 \mathrm{mM})$ were prepared and diluted with the $N$-[2-hydroxyethyl]piperazine- $N N^{\prime}$-2-ethanesulfonic acid (HEPES) buffer that was used in the assays, to obtain a compound concentration of $3 \mathrm{mM}$. After a short period of time after dilution, compound 18 precipitated, while the other compounds stayed in solution. After $15 \mathrm{~h}$ at room temperature, compound $\mathbf{1 7}$ also started to precipitate, while $\mathbf{1 2}$ precipitated after $48 \mathrm{~h}$ and 15 after about 1 week. The precipitated compounds were collected by filtration, dried, and NMR spectra were recorded showing that the precipitated compounds were structurally identical to the original anthraquinone derivatives. This result indicates that the compounds were not degraded, but precipitated upon dilution with buffer solutions due to the lower solubility in the presence of high salt concentrations probably due to the formation of poorly soluble salts of the anthraquinone sulfonic acids with cations in the buffer (HEPES and/or calcium). Since precipitation in most cases only occurred after several hours, testing of high concentrations was always performed with freshly prepared solutions.

Investigation of anthraquinone derivatives as potential inhibitors of nucleoside triphosphate diphosphohydrolases by capillary electrophoresis

Inhibition of rat NTPDases1, 2, and 3 was performed essentially as previously described using a capillary electrophoresis (CE) method [27]. Membrane preparations derived from transfected cells containing rat NTPDase1, NTPDase2, or NTPDase3 were employed. A fixed substrate concentration of $400 \mu \mathrm{M}$ was used. Test compounds were initially screened at a concentration of $1 \mathrm{mM}$. For compounds which showed about $50 \%$ inhibition or more, $\mathrm{IC}_{50}$ values were
Fig. 2 Synthesis of aryl- and arylalkylaminoanthraquinone derivatives 20-22 and 23-26 (for $\mathrm{R}$ see Table 1)

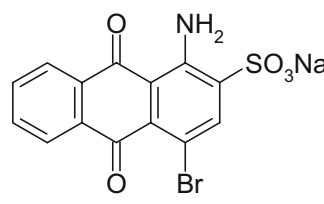

8 Bromaminic acid<smiles>[R20]Nc1cc(S(=O)(=O)O[Na])c(N)c2c1C(=O)c1cc(C)ccc1C2=O</smiles><smiles>Cc1cc(Br)c2c(c1N)C(=O)c1ccccc1C2=O</smiles>

9

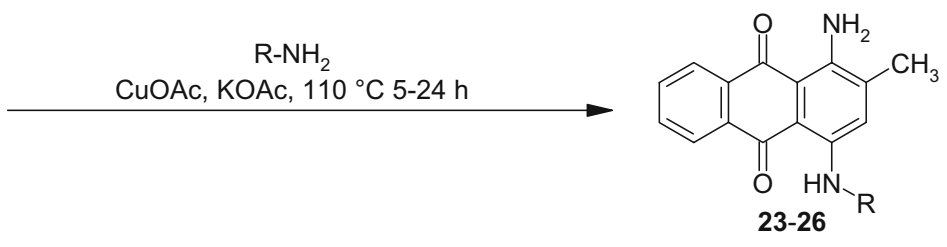


Fig. 3 Synthesis of bromaminic acid esters 27-30, bromaminic acid amides 31-33, and bis(bromaminic acid) amides $\mathbf{3 4}$ and $\mathbf{3 5}$

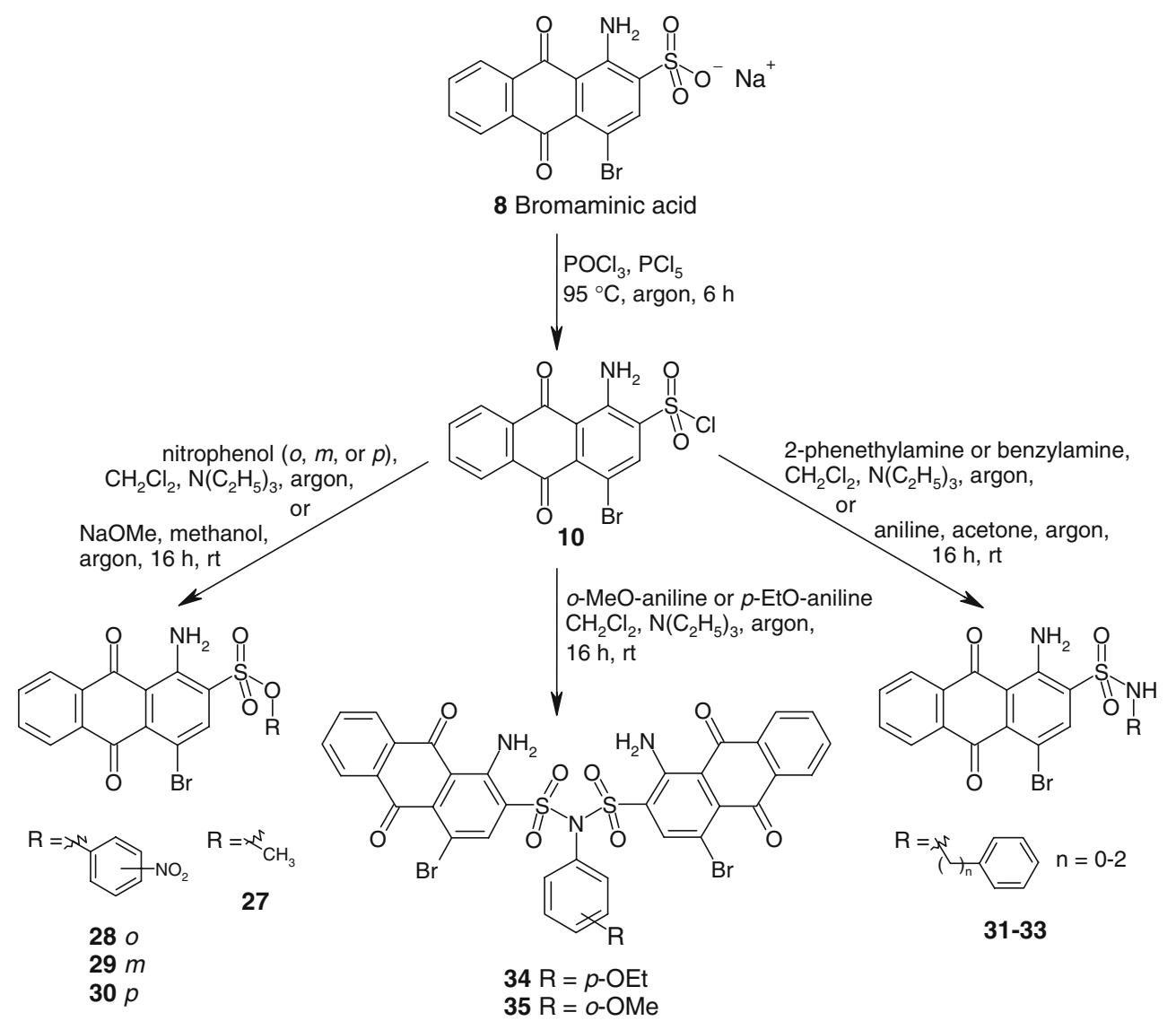

determined with six to eight different concentrations of inhibitor spanning about three orders of magnitude. After stopping the reaction by heating, an aliquot was subjected to $\mathrm{CE}$ analysis with UV detection at $210 \mathrm{~nm}$. Under the applied conditions less than $10 \%$ of substrate was converted by the enzymes. $\mathrm{K}_{\mathrm{i}}$ values were calculated from $\mathrm{IC}_{50}$ values as previously described assuming a competitive inhibition mechanism [27].

\section{Structure-activity relationships}

Even though the investigated 1-amino-2-sulfo-4-ar(alk)ylaminoanthraquinone derivatives exhibited only a partial structure of RB-2 and were much smaller than the parent compound, many of them were similarly or even more active as NTPDase inhibitors (Table 1). For example, compound 18 bearing a $p$-chlorophenylamino residue was a potent, nonselective NTPDase inhibitor $\left(\mathrm{K}_{\mathrm{i}} 16-18 \mu \mathrm{M}\right)$. While NTPDase2 and 3 were quite tolerant with regard to the substituent in the 4-position accepting a large variety of differentially substituted arylamino residues and even a 3,4-dimethoxyphenethylamino residue, structure-activity relationships (SARs) of NTPDase1 were more restricted: phenylamino (11), $m$-methylphenylamino (13), and particularly $o, p$-dimethylphenylamino (15) and $p$-chlorophenylamino (18) were best tolerated, while monosubstitution in the ortho-position of the phenylamino residue $(\mathbf{1 2}, \mathbf{1 6}, \mathbf{1 7})$ or replacement of the phenyl ring by 1-naphthyl (20) or a 3,4-dimethoxyphenethyl residue (22) were not well tolerated by rat NTPDase1. On the other hand, a 2-naphthyl ring was very well tolerated by NTPDase1: compound 21 was the most potent NTPDase1 inhibitor of the present series with a $K_{i}$ value of $0.328 \mu \mathrm{M}$; it was less potent at NTPDase3 ( $\left.\mathrm{K}_{\mathrm{i}} 2.22 \mu \mathrm{M}\right)$ and much less potent at NTPDase2 $(19.1 \mu \mathrm{M})$. Small $p$-substituents on the phenyl ring ( $p$-chloro, $p$-methyl) were well accepted by NTPDase1, while an acetylamino residue in the $p$-position was detrimental. Compound $\mathbf{2 0}$ was the most potent and selective inhibitor of rat NTPDase 3 and not inhibitory to rat NTPDase1 and 2 even at high, millimolar concentrations. Rat NTPDase3 appears to have a lipophilic pocket which can accommodate a 1-naphthylamino residue in the 4-position. Concentration-inhibition curves of the most potent nonselective NTPDase inhibitor 18 (PSB-069) at the three investigated NTPDases and of the NTPDase3selective inhibitor 20 (PSB-06126) are shown in Fig. 4.

An unsubstituted sulfonate group in the 2-position of the anthraquinone scaffold was essential for inhibitory activity. Replacement of the sulfonate by a methyl group (23-26) abolished activity. Bromaminic acid derivatives, in which the sulfonic acid group was converted to sulfonic acid esters $(\mathbf{2 7 - 3 0})$ or sulfonamides (31-33), were also totally 
Table 1 Inhibitory potencies of anthraquinone derivatives at rat NTPDase1, 2, and 3 determined by capillary electrophoresis ${ }^{\mathrm{a}}$<smiles>[R]Nc1cc(S(N)(=O)=O)c(N)c2c1C(=O)c1ccccc1C2=O</smiles>

11-22<smiles>[R]Nc1cc(C)c(N)c2c1C(=O)c1ccccc1C2=O</smiles>

23-26<smiles>[R]S(=O)(=O)c1cc(Br)c2c(c1N)C(=O)c1ccccc1C2=O</smiles>

27-33

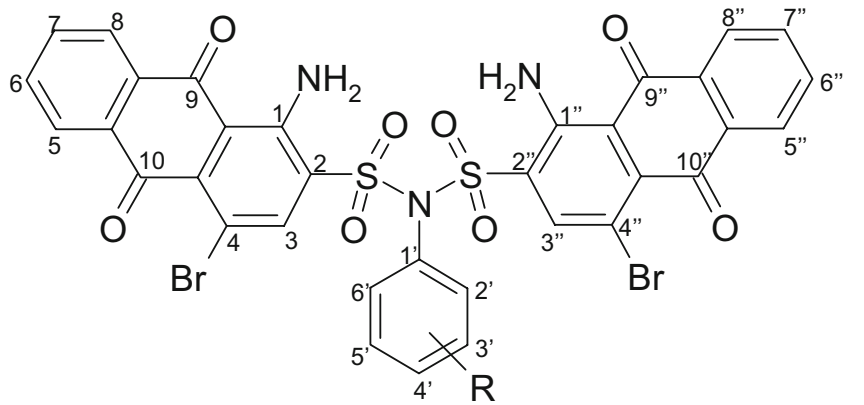

34,35

\begin{tabular}{|c|c|c|c|c|}
\hline \multirow[t]{2}{*}{ Inhibitor } & \multirow[t]{2}{*}{$\mathrm{R}$} & \multicolumn{3}{|c|}{$\mathrm{K}_{\mathrm{i}}(\mu \mathrm{M}) \pm \mathrm{SEM}$ (or percent inhibition at $1 \mathrm{mM}$ ) } \\
\hline & & NTPDase1 & NTPDase2 & NTPDase3 \\
\hline 1 & ARL 67156 [27] & $27.0 \pm 0.0$ & $(50 \%)$ & $112 \pm 0$ \\
\hline 5 & Reactive blue 2 (RB-2) [27] & $20.0 \pm 0.0$ & $24.20 \pm 0.06$ & $1.10 \pm 0.03$ \\
\hline \multicolumn{5}{|c|}{ 1-Amino-4-aryl(alkyl)amino-2-sulfo-anthraquinones } \\
\hline 11 & Phenyl & $49.1 \pm 5.1$ & $35.8 \pm 6.1$ & $14.3 \pm 1.5$ \\
\hline 12 & 2-Methylphenyl & $(25 \%)$ & $25.7 \pm 5.1$ & $23.0 \pm 2.5$ \\
\hline 13 & 3-Methylphenyl & $51.5 \pm 0.4$ & $12.8 \pm 0.9$ & $19.1 \pm 6.0$ \\
\hline 14 & 2,3-Dimethylphenyl & $(67 \%)^{\mathrm{b}}$ & $22.7 \pm 3.4$ & $38.5 \pm 5.0$ \\
\hline 15 & 2,4-Dimethylphenyl & $18.0 \pm 3.5$ & $15.6 \pm 2.5$ & $41.8 \pm 5.5$ \\
\hline 16 & 2-Methoxyphenyl & $(57 \%)$ & $53.8 \pm 5.7$ & $17.6 \pm 6.6$ \\
\hline 17 & 2-Ethoxyphenyl & $(17 \%)$ & $40.8 \pm 11.1$ & $58.0 \pm 12.7$ \\
\hline 18 & 4-Chlorophenyl & $15.7 \pm 3.4$ & $18.0 \pm 2.0$ & $16.4 \pm 1.6$ \\
\hline 19 & 4-Acetylaminophenyl & $(15 \%)$ & $486 \pm 18$ & $343 \pm 63$ \\
\hline 20 & 1-Naphthyl & $(0 \%)$ & $(0 \%)$ & $1.5 \pm 0.1$ \\
\hline 21 & 2-Naphthyl & $0.328 \pm 0.110$ & $19.1 \pm 1.6$ & $2.22 \pm 1.03$ \\
\hline 22 & 3,4-Dimethoxy-phenethyl & $173 \pm 6$ & $54.1 \pm 6.8$ & $23.4 \pm 0.4$ \\
\hline \multicolumn{5}{|c|}{ 1-Amino-4-arylamino-2-methyl-anthraquinones } \\
\hline 23 & Phenyl & $(0 \%)$ & $(0 \%)$ & $(0 \%)$ \\
\hline 24 & 3-Methylphenyl & $(0 \%)$ & $(0 \%)$ & $(0 \%)$ \\
\hline 25 & 4-Methylphenyl & $(0 \%)$ & $(0 \%)$ & $(0 \%)$ \\
\hline 26 & 1-Naphthyl & $(0 \%)$ & $(0 \%)$ & $(0 \%)$ \\
\hline \multicolumn{5}{|c|}{ 1-Amino-4-bromo-anthraquinone 2-sulfonates or 2-sulfonamides } \\
\hline 27 & Methoxy & $(0 \%)$ & $(0 \%)$ & $(0 \%)$ \\
\hline 28 & 2-Nitrophenoxy & $(0 \%)$ & $(0 \%)$ & $(0 \%)$ \\
\hline 29 & 3-Nitrophenoxy & $(0 \%)$ & $(0 \%)$ & $(0 \%)$ \\
\hline 30 & 4-Nitrophenoxy & $(0 \%)$ & $(0 \%)$ & $(0 \%)$ \\
\hline 31 & Phenylamino & $(0 \%)$ & $(0 \%)$ & $(0 \%)$ \\
\hline 32 & Benzylamino & $(0 \%)$ & $(0 \%)$ & $(0 \%)$ \\
\hline 33 & Phenethylamino & $(0 \%)$ & $(0 \%)$ & $(0 \%)$ \\
\hline
\end{tabular}


Table 1 (continued)

\begin{tabular}{|c|c|c|c|c|}
\hline \multirow[t]{2}{*}{ Inhibitor } & \multirow[t]{2}{*}{$\mathrm{R}$} & \multicolumn{3}{|c|}{$\mathrm{K}_{\mathrm{i}}(\mu \mathrm{M}) \pm \mathrm{SEM}$ (or percent inhibition at $1 \mathrm{mM}$ ) } \\
\hline & & NTPDase1 & NTPDase2 & NTPDase3 \\
\hline \multicolumn{5}{|c|}{ Bis-(1-amino-4-bromo-anthraquinone) sulfonamides } \\
\hline 34 & $4^{\prime}$-Ethoxy & $(0 \%)$ & $(0 \%)$ & $(0 \%)$ \\
\hline 35 & 2'-Methoxy & $(0 \%)$ & $(0 \%)$ & $(0 \%)$ \\
\hline
\end{tabular}

${ }^{\mathrm{a}}$ The results are means \pm SEM of three separate experiments each run in duplicate

${ }^{\mathrm{b}}$ Curve could not be determined: inhibition was not concentration dependent; there was no inhibition at $100 \mu \mathrm{M}$

inactive. Thus, a negative charge (a free sulfonate group) appeared to be required for NTPDase inhibition. This is in agreement with previous studies on sulfonate dyes and related compounds, which showed that sulfonate groups in certain positions of the molecules were important for ectonucleotidase inhibitory activity [23, 34].

In order to investigate the inhibition mechanism of this class of NTPDase inhibitors, kinetics of NTPDase 3 were exemplarily determined in the absence and in the presence of compound $18(10,20$, and $30 \mu \mathrm{M})$. While the $\mathrm{V}_{\max }$ value was not affected by the inhibitor, the $\mathrm{K}_{\mathrm{m}}$ value increased with increasing concentration of inhibitor indicating a competitive mechanism of inhibition (for Lineweaver-Burk plot see Fig. 5).

The present study is the first one to systematically investigate the SARs of anthraquinone derivatives derived from RB-2 at defined NTPDase isoenzymes. We could confirm previous findings by Tuluc et al. [37] that anthraquinone derivatives with only one substituted phenyl ring at the 4-amino group, which are much smaller than RB-2, can exhibit ectonucleotidase inhibitory activity. However, compound 11 (also known as acid blue 25) was inactive (at $100 \mu \mathrm{M})$ in their study investigating ATP degradation in rat vas deferens tissue [37]. Like RB-2, its truncated derivatives
Fig. 4 Concentration-inhibition curves of selected anthraquinone derivatives. Top: curves of the nonselective NTPDase inhibitor 18 at NTPDase1, 2, and 3. Bottom: curve of the NTPDase 3 inhibitor 20

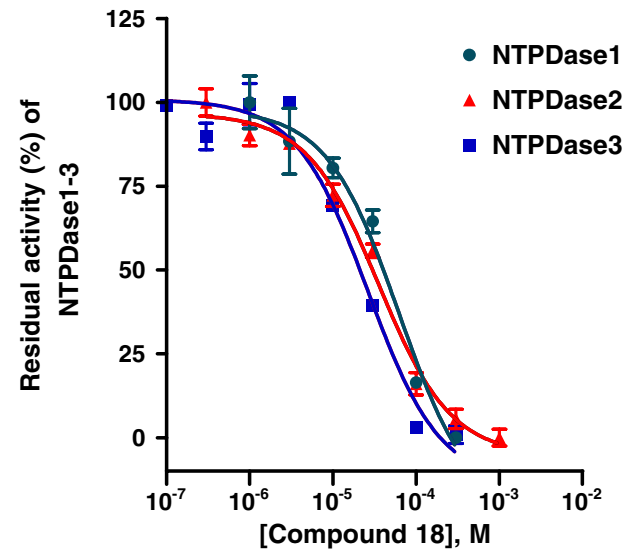<smiles>Nc1c(S(N)(=O)=O)cc(Nc2ccc(Cl)cc2)c2c1C(=O)c1ccccc1C2=O</smiles>

18 (PSB-069)

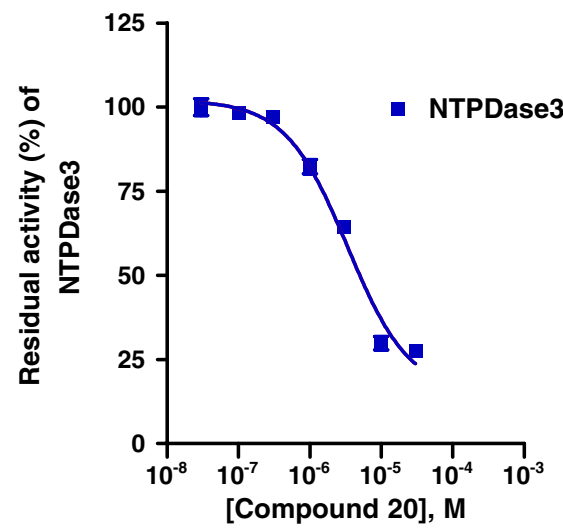<smiles>CS(=O)(=O)c1cc(Nc2cccc3ccccc23)c2c(c1N)C(=O)c1ccccc1C2=O</smiles> 


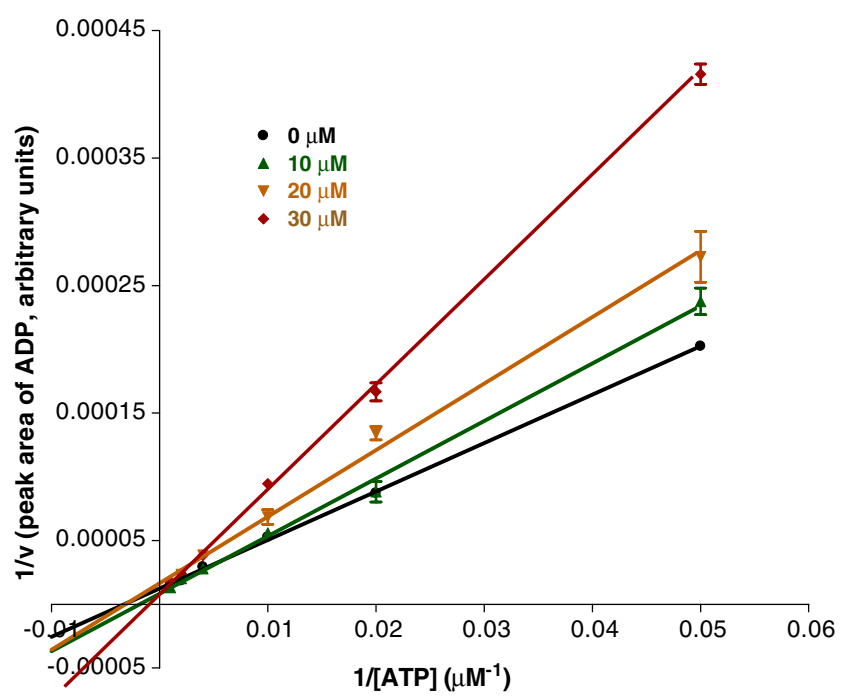

Fig. 5 Lineweaver-Burk plot for rat NTPDase3 kinetics in the absence and presence of different concentrations of inhibitor $\mathbf{1 8}$

also interact with $\mathrm{P} 2$ receptors $[37,45,48]$. However, the SARs are clearly different. For example, 16 (PSB-716) was shown to be a potent $\mathrm{P} 2 \mathrm{Y}_{2}$ antagonist $\left(\mathrm{IC}_{50}\right.$ ca. $\left.9 \mu \mathrm{M}\right)$ [45], but it is only a weak NTPDase1 inhibitor. Compound 19 was also a potent inhibitor at $\mathrm{P}_{2} \mathrm{Y}_{2}\left(\mathrm{IC}_{50} 6-12 \mu \mathrm{M}\right)$ [45], but nearly inactive at all three NTPDases tested.

\section{Conclusions}

We have investigated 25 anthraquinone derivatives related to RB-2 for their potency at inhibiting rat NTPDases1, 2, and 3 in order to obtain initial information about their structureactivity relationships. While 11 of the compounds had previously been reported, 14 compounds are new and their syntheses and physicochemical characterization are described for the first time. Certain 1-amino-2-sulfo-4-arylaminoanthraquinones were identified as potent NTPDase inhibitors. While the 4-chlorophenylamino derivative $\mathbf{1 8}$ was a nonselective inhibitor $\left(\mathrm{K}_{\mathrm{i}} 16-18 \mu \mathrm{M}\right)$, the 4-(1-naphthylamino) derivative 20 was very potent and selective for rat NTPDase 3 versus rat NTPDase1 and 2. In contrast, its 2-naphthylamino isomer $\mathbf{2 1}$ was a very potent NTPDase1 inhibitor $\left(\mathrm{K}_{\mathrm{i}} 0.328 \mu \mathrm{M}\right)$. For future studies it would be of interest to investigate potential species differences of these and other NTPDase inhibitors. Furthermore, it will be important to investigate the potency of some of these compounds at other ectonucleotidases, including ecto-5'-nucleotidase, nucleotide pyrophosphatases/ phosphodiesterases (NPPs), and alkaline phosphatases, and to determine their profile at the various $\mathrm{P} 2 \mathrm{Y}$ and $\mathrm{P} 2 \mathrm{X}$ receptor subtypes, in order to be able to fully assess their usefulness as pharmacological tools. The compounds described will be good starting points for further optimization.
Acknowledgements Y.B. and J.I. were supported by DAAD (Deutscher Akademischer Austauschdienst) scholarships. C.E.M. and Y.B. and H.Z. are grateful for support by the Deutsche Forschungsgemeinschaft (DFG, GRK804 and Zi 140/17-3, respectively). We thank Christina Ising, student of molecular biomedicine, for testing some of the compounds.

\section{Appendix}

Experimental section

\section{Reagents and chemicals}

4-(2-Hydroxyethyl)piperazine-1-ethanesulfonic acid (HEPES), ATP, $\mathrm{MgCl}_{2} \cdot 6 \mathrm{H}_{2} \mathrm{O}$, and tris(hydroxymethyl)aminomethane (Trizma Base), penicillin and streptomycin were purchased from Sigma-Aldrich (Taufkirchen, Germany). Culture medium was obtained from Invitrogen (Karlsruhe, Germany). Leupeptin, pepstatin A, chymostatin, and antipain were received from Calbiochem (Schwalbach, Germany).

Bromaminic acid (8) and 1-amino-4-bromo-2-methylanthraquinone (9) were obtained from Sigma-Aldrich (Taufkirchen, Germany). Aniline derivatives were a gift from Bayer AG (through Fonds der Chemischen Industrie). Liquid aniline derivatives were purified by distillation before use in case they showed a dark brown color. Solvents were dried according to standard methods when required. All other chemicals were obtained from standard commercial sources or prepared as described below. Anthraquinone derivatives 11-19 were prepared as recently published $[45,46]$.

\section{Instruments}

NMR spectra were recorded on a Bruker Avance 500 spectrometer. Electron impact mass spectra (EI-MS) were obtained on an MS 50 instrument of the company A.E.I., or a MAT $95 \mathrm{XL}$ instrument of Thermoquest. Polar compounds were analyzed by electrospray ionization using the API 2000 LC-MS instrument from Applied Biosystems. Elemental analyses were performed with a VarioEL instrument of Elementar Analysensysteme GmbH. Melting points were determined on a Gallenkamp apparatus, or a B530 or a B-545 apparatus from Büchi. Melting points of sodium sulfonates were usually not determined because they are $>300^{\circ} \mathrm{C}$. Reactions were monitored by thin-layer chromatography (TLC) using silica gel plates $\mathrm{F}_{254}$ and/or RP silica gel plates $\mathrm{F}_{254}$. For microwave reactions a CEM Focused $^{\mathrm{TM}}$ Microwave Synthesis type Discover apparatus was used. A freeze dryer (CHRIST ALPHA 1-4 LSC) was used for lyophilization. 
Synthetic procedures and analytical data of anthraquinone derivatives

\section{Sodium 1-amino-4-(1-naphthylamino)-9,10-dioxo-9, 10-dihydroanthracene 2-sulfonate (20)}

Bromaminic acid sodium salt $(0.500 \mathrm{~g}, 1.25 \mathrm{mmol}), \mathrm{Na}_{2} \mathrm{CO}_{3}$ $(0.175 \mathrm{~g})$, and $\mathrm{CuSO}_{4}(0.030 \mathrm{~g})$ were dissolved in $10 \mathrm{ml}$ of water. Then $2 \mathrm{~g}(14 \mathrm{mmol})$ of 1 -aminonaphthalene was added and the reaction mixture was stirred for $16 \mathrm{~h}$ at $105^{\circ} \mathrm{C}$. After completion of the reaction the mixture was cooled for $4 \mathrm{~h}$ at $4^{\circ} \mathrm{C}$, and the formed precipitate was filtered off. The precipitate was washed with $10 \mathrm{ml}$ of water and subsequently with $200 \mathrm{ml}$ of dichloromethane until the filtrate became colorless. The residue was dried under vacuum. Yield: $0.281 \mathrm{~g}(49 \%) ; \mathrm{mp}>300^{\circ} \mathrm{C}$. ${ }^{1} \mathrm{H}-\mathrm{NMR}$ [dimethyl sulfoxide (DMSO) $-d_{6}, 500 \mathrm{MHz}, 303 \mathrm{~K}$ ]: $\delta(\mathrm{ppm})=7.49(\mathrm{br}, 1 \mathrm{H}$, $\left.\mathrm{NH}_{2}\right) ; 7.50\left(\mathrm{~d}, 1 \mathrm{H},{ }^{3} J=7.3 \mathrm{~Hz}\right.$, naphthalene); 7.58-7.63 (m, $3 \mathrm{H}$, naphthalene); $7.80(\mathrm{~s}, 1 \mathrm{H}, \mathrm{C} 3 \mathrm{H}) ; 7.84-7.90(\mathrm{~m}, 3 \mathrm{H}$, $\mathrm{C} 6 \mathrm{H}, \mathrm{C} 7 \mathrm{H}$, naphthalene); 8.02, 8.08 (m, 2H, naphthalene); 8.32 (m, 2H, C5H, C8H); 10.12 (br, 1H, NH $\left.{ }_{2}\right) ; 12.51$ (s, $1 \mathrm{H}$, $\mathrm{NH}) .{ }^{13} \mathrm{C}-\mathrm{NMR}$ (DMSO- $\left.d_{6}, 125 \mathrm{MHz}, 303 \mathrm{~K}\right): \delta(\mathrm{ppm})=$ 109.23, 111.46 (C4a, C9a); 121.55, 121.97 (C2', C4'); 122.92 (C3); 125.76, 126.20 (2C), 126.24, 126.91, 127.12, 128.67, 129.00 (C5, C8, C5', C6', C7', C8', C4a', C8a'); 132.94, 133.38, 133.78, 134.40, 134.48, 135.21 (C6, C7, C8a, C10a, C1', C3'); 142.58, 143.15, 144.49 (C1, C2, C4); $181.92,182.95(\mathrm{C} 9, \mathrm{C} 10) . \mathrm{FAB} \mathrm{m} / \mathrm{z}(\%)=466(100$, $\left.\mathrm{C}_{25} \mathrm{H}_{15} \mathrm{~N}_{2} \mathrm{O}_{5} \mathrm{SNa}\right) ; 444$ (46, $\mathrm{C}_{25} \mathrm{H}_{15} \mathrm{~N}_{2} \mathrm{O}_{5} \mathrm{~S}$ ).

\section{Sodium 1-amino-4-(2-naphthylamino)-9,10-dioxo-9, 10-dihydroanthracene 2-sulfonate (21)}

The synthesis was performed in analogy to a recently described procedure [46]. To a 5-ml microwave reaction vial equipped with a magnetic stirring bar were added bromaminic acid sodium salt $(0.081 \mathrm{~g}, 0.20 \mathrm{mmol})$ and 1-aminonaphthalene $(80 \mathrm{mg}, 0.40 \mathrm{mmol})$, followed by a buffer solution consisting of $4 \mathrm{ml}(0.2 \mathrm{M})$ aq. $\mathrm{Na}_{2} \mathrm{HPO}_{4}$ solution (pH 9.6) and $1 \mathrm{ml}(0.12 \mathrm{M})$ of $\mathrm{NaH}_{2} \mathrm{PO}_{4}(\mathrm{pH} 4.2)$. A catalytic amount (ca. $0.002-0.003 \mathrm{~g}$ ) of finely powdered elemental copper was added. The mixture was capped and irradiated in the microwave oven $(100 \mathrm{~W})$ for $5 \mathrm{~min}$ at $120^{\circ} \mathrm{C}$. Then the reaction mixture was cooled to room temperature (RT), and the product was purified using the following procedure. The contents of the vial were filtered to remove the elemental copper. Then water (approximately $200 \mathrm{ml}$ ) was added to the filtrate and the aqueous solution was extracted with chloroform $(200 \mathrm{ml})$. The extraction procedure was repeated until the organic layer became colorless (2-3 times). Then the aqueous layer was reduced by rotary evaporation to a volume of ca. $10 \mathrm{ml}$, which was subsequently submitted to flash column chromatography using RP-18 silica gel and water as an eluent. The polarity of the eluent was then gradually decreased by the addition of methanol in the following steps: $20,40,60,80$, and $100 \%$. Fractions containing blue product were collected. The pooled product-containing fractions were evaporated under reduced pressure to remove the methanol, and the remaining water was subsequently removed by lyophilization to yield 21 as blue powder. Yield: $0.046 \mathrm{~g}$ (50\%); mp $>300^{\circ} \mathrm{C} .{ }^{1} \mathrm{H}-\mathrm{NMR}: \delta 7.49$ (m, 3H, naphthalene); $7.76(\mathrm{~d}, 1 \mathrm{H}$, naphthalene); $7.86(\mathrm{~m}, 2 \mathrm{H}, 6-\mathrm{H}, 7-\mathrm{H}) ; 7.92(\mathrm{~d}$, $1 \mathrm{H}$, naphthalene); $8.00(\mathrm{~d}, 1 \mathrm{H}$, naphthalene); $8.09(\mathrm{~s}, 1 \mathrm{H}, 3-$ H); 8.29 (m, 2H, 5-H, 8-H); 10.12 (br, 2H, 1- $\left.\mathrm{NH}_{2}\right) ; 12.16$ (s, 1H, NH). ${ }^{13} \mathrm{C}-\mathrm{NMR}: \delta 109.4,112.0$ (C4a, C9a); 119.3, 123.1 (C2', C4'); 123.3 (C3); 125.3, 126.1, 126.2, 126.9, 127.3, 127.8, 129.6, 130.5 (C5, C8, C5', C6', C7', C8', C4a', C8a'); 133.0, 133.4, 133.7, 134.0, 134.3, 137.1 (C6, C7, C8a, C10a, C1', C3'); 140.7, 142.90, 144.6 (C1, C2, C4); 182.0 (C9), 182.8 (C10). LC-MS (m/z): $462\left[\mathrm{M}-\mathrm{Na}+\mathrm{NH}_{4}{ }^{+}\right]^{+}, 445$ $[\mathrm{M}-\mathrm{Na}]^{+}, 443[\mathrm{M}-\mathrm{Na}]^{-}$. Purity by high-performance liquid chromatography (HPLC)-UV (254 nm)-electrospray ionization (ESI)-MS: 98\%.

\section{Sodium 1-amino-4-(3,4-dimethoxyphenethylamino)-9, 10-dioxo-9,10-dihydroanthracene 2-sulfonate (22)}

Bromaminic acid sodium salt (1.0 g, $2.5 \mathrm{mmol}), \mathrm{Na}_{2} \mathrm{CO}_{3}$ $(0.210 \mathrm{~g})$, and $\mathrm{CuSO}_{4}(0.070 \mathrm{~g})$ were suspended in $20 \mathrm{ml}$ of water. Then 3,4-dimethoxyphenethylamine $(670 \mu l$, $0.725 \mathrm{~g}, 4.0 \mathrm{mmol})$ was added and the reaction mixture was heated at $60^{\circ} \mathrm{C}$. Then another portion of 3,4-dimethoxyphenethylamine $(1 \mathrm{ml}, 1.09 \mathrm{~g}, 6 \mathrm{mmol})$ was added and the reaction mixture was stirred for $6 \mathrm{~h}$ at $100^{\circ} \mathrm{C}$. After the reaction was completed the mixture was cooled and neutralized by the addition of diluted aq. $\mathrm{HCl}$ solution. Then $20 \mathrm{ml}$ of water containing $1 \mathrm{ml}$ of saturated aq. $\mathrm{NaCl}$ solution were added. The blue-colored solid material was filtered off and washed twice with $20 \mathrm{ml}$ of a saturated $\mathrm{NaCl}$ solution, and subsequently three times with $20 \mathrm{ml}$ of dichloromethane each. The residue was dissolved in $200 \mathrm{ml}$ of a mixture of hot water:methanol (1:3) and filtered. The filtrate was evaporated to dryness yielding a blue-violet product, which was further purified by preparative HPLC in analogy to a described procedure [45]. Yield: $54 \%$; $\mathrm{mp}>$ $300{ }^{\circ} \mathrm{C} .{ }^{1} \mathrm{H}-\mathrm{NMR}$ (DMSO- $\left.d_{6}, 303 \mathrm{~K}, 500 \mathrm{MHz}\right): \delta(\mathrm{ppm})=$ 2.90 (t, $\left.2 \mathrm{H},{ }^{3} \mathrm{~J}=6.9 \mathrm{~Hz}, \mathrm{ArCH}_{2}\right) ; 3.63\left(\mathrm{dt},{ }^{3} J_{\mathrm{HNCH}}=5.3 \mathrm{~Hz}\right.$, ${ }^{3} J_{\mathrm{CH} 2 \mathrm{CH} 2}=6.9 \mathrm{~Hz} \mathrm{NHCH}$ ); 3.71 (s, $3 \mathrm{H}, \mathrm{C}^{\prime}-\mathrm{OCH}_{3}$ or $\mathrm{C}^{\prime}{ }^{\prime}-$ $\left.\mathrm{OCH}_{3}\right) ; 3.77\left(\mathrm{~s}, 3 \mathrm{H}, \mathrm{C}^{\prime}-\mathrm{OCH}_{3}\right.$ or $\left.\mathrm{C}^{\prime}-\mathrm{OCH}_{3}\right) ; 6.84(\mathrm{dd}, 1 \mathrm{H}$, $\left.{ }^{3} J=8.0 \mathrm{~Hz},{ }^{4} J=1.7 \mathrm{~Hz}, \mathrm{C} 6{ }^{\prime} \mathrm{H}\right) ; 6.89\left(\mathrm{~d}, 1 \mathrm{H},{ }^{3} J=8.2 \mathrm{~Hz}, \mathrm{C}^{\prime}\right.$ $\mathrm{H}) ; 6.97\left(\mathrm{~d}, 1 \mathrm{H},{ }^{4} J=1.6 \mathrm{~Hz}, \mathrm{C} 2^{\prime} \mathrm{H}\right) ; 7.40\left(\mathrm{br}, 1 \mathrm{H}, \mathrm{NH}_{2}\right) ; 7.77-$ $7.80(\mathrm{~m}, 2 \mathrm{H}, \mathrm{C} 6 \mathrm{H}, \mathrm{C} 7 \mathrm{H}) ; 7.81(\mathrm{~s}, 1 \mathrm{H}, \mathrm{C} 3 \mathrm{H}) ; 8.19-8.26(\mathrm{~m}$, $2 \mathrm{H}, \mathrm{C} 5 \mathrm{H}, \mathrm{C} 8 \mathrm{H}) ; 10.08$ (br, $\left.1 \mathrm{H}, \mathrm{NH}_{2}\right) ; 10.76\left(\mathrm{t}, 1 \mathrm{H},{ }^{3} \mathrm{~J}=\right.$ $5.2 \mathrm{~Hz}, \mathrm{NH}$ ). ${ }^{13} \mathrm{C}-\mathrm{NMR}$ (DMSO- $d_{6}, 303 \mathrm{~K}, 125 \mathrm{MHz}$ ): $\delta$ $(\mathrm{ppm})=34.88\left(\mathrm{ArCH}_{2}\right) ; 44.35\left(\mathrm{NHCH}_{2}\right) ; 55.49,55.68\left(\mathrm{C}^{\prime}-\right.$ $\left.\mathrm{OCH}_{3}, \mathrm{C}^{\prime}-\mathrm{OCH}_{3}\right) ; 109.07,109.29$ (C4a, C9a); 112.23, 
112.94 (C2', C5'); 120.70, 121.02 (C3, C6'); 125.79, 126.01 (C5, C8); $131.52\left(\mathrm{Cl}^{\prime}\right) ; 132.56,132.64,134.05,134.10$ (C6, C7, C8a, C10a); 143.20, 143.72, 145.06 (C1, C2, C4); 147.57, 148.87 (C3', C4'); 180.97, 181.74 (C9, C10).

General procedure for the synthesis of 4-substituted 1-amino-2-methylanthraquinone derivatives (23-26)

1-Amino-4-bromo-2-methylanthraquinone (9), potassium acetate, and copper(I) acetate were put together into a mortar and pestled until a finely ground powder was obtained. The mixture was then transferred to a round-bottom flask and the appropriate aniline, or aminonaphthalene derivative, respectively, was added. The mixture was then heated at $100^{\circ} \mathrm{C}$ under an argon atmosphere upon stirring for 5-24 h. After cooling, ethanol $(5-10 \mathrm{ml})$ was added and the solid residue was collected by filtration, washed with ethanol, $2 \mathrm{~N}$ aqueous $\mathrm{HCl}$ solution, and water $(15 \mathrm{ml}$ each) and finally recrystallized from pyridine (if necessary).

\section{1-Amino-2-methyl-4-phenylaminoanthraquinone (23)}

The compound was synthesized from $500 \mathrm{mg}(1.6 \mathrm{mmol})$ of 9 and $2 \mathrm{ml}(2.04 \mathrm{~g}, 22 \mathrm{mmol})$ of aniline in the presence of $350 \mathrm{mg}(3.6 \mathrm{mmol})$ of potassium acetate and $30 \mathrm{mg}$ (0.16 mmol) of copper(I) acetate. Reaction time: $5 \mathrm{~h}$.

Yield: $331 \mathrm{mg}(64 \%)$; mp: $243^{\circ} \mathrm{C} .{ }^{1} \mathrm{H}-\mathrm{NMR}$ (DMSO- $d_{6}$, $500 \mathrm{MHz}) \delta(\mathrm{ppm})=2.25\left(\mathrm{~d}, 3 \mathrm{H},{ }^{4} J=0.6 \mathrm{~Hz}, \mathrm{CH}_{3}\right) ; 7.18(\mathrm{tt}$, $\left.1 \mathrm{H},{ }^{3} J=7.4 \mathrm{~Hz},{ }^{4} J=1.2 \mathrm{~Hz} \mathrm{C} 4^{\prime} \mathrm{H}\right) ; 7.31\left(\mathrm{dm}, 2 \mathrm{H},{ }^{3} J=7.6 \mathrm{~Hz}\right.$, $\left.\mathrm{C} 2^{\prime} \mathrm{H}, \mathrm{C} 6^{\prime} \mathrm{H}\right) ; 7.43\left(\mathrm{tm}, 2 \mathrm{H},{ }^{3} J=7.9 \mathrm{~Hz}, \mathrm{C}^{\prime} \mathrm{H}, \mathrm{C}^{\prime} \mathrm{H}\right) ; 7.44$ (s, $\left.1 \mathrm{H},{ }^{4} J=0.6 \mathrm{~Hz}, \mathrm{C} 3 \mathrm{H}\right) ; 7.82\left(\mathrm{dd}, 1 \mathrm{H},{ }^{3} J=6.3 \mathrm{~Hz},{ }^{4} J=\right.$ $2.1 \mathrm{~Hz}, \mathrm{C} 6 \mathrm{H}$ or $\mathrm{C} 7 \mathrm{H}) ; 7.83\left(\mathrm{dd}, 1 \mathrm{H},{ }^{3} \mathrm{~J}=6.3 \mathrm{~Hz},{ }^{4} \mathrm{~J}=2.1 \mathrm{~Hz}\right.$, $\mathrm{C} 6 \mathrm{H}$ or $\mathrm{C} 7 \mathrm{H}) ; 8.24-8.29$ (m, 2H, C5H, C8H), 8.49 (br, $2 \mathrm{H}$, $\left.\mathrm{NH}_{2}\right) ; 12.25$ (s, $\left.1 \mathrm{H}, \mathrm{NH}\right) .{ }^{13} \mathrm{C}-\mathrm{NMR}$ (DMSO- $d_{6}, 125 \mathrm{MHz}$, $303 \mathrm{~K}): \delta(\mathrm{ppm})=18.68\left(\mathrm{CH}_{3}\right) ; 108.08,109.62(\mathrm{C} 4 \mathrm{a}, \mathrm{C} 9 \mathrm{a})$; 123.19 (2C, C2', C6'); 124.43 (C4'); 124.52 (C3); 126.00, 126.13 (C5, C8); 129.82 (2C, C3', C5'); 132.83, 133.03 (C6, C7); 133.96, 134.12 (C8a, C10a); 137.55 (C2); 139.40 (C1'); 142.02 (C4); 147.23 (C1); 181.97, 182.04 (C9, C10). The assignment of the signals was based on one- and twodimensional NMR spectra; however, some signals could not be unambiguously assigned.

EI-MS: $\mathrm{m} / \mathrm{z}(\%)=328\left(100 ;\left[\mathrm{C}_{21} \mathrm{H}_{16} \mathrm{~N}_{2} \mathrm{O}_{2}\right]^{++}\right) ; 311(8 ;$ $\left[\mathrm{C}_{21} \mathrm{H}_{13} \mathrm{NO}_{2}\right]^{+}$). High-resolution mass spectrometry (HRMS) (70 eV, EI): Calcd: : 328.121178. Found $328.1209 \Rightarrow$ $\mathrm{C}_{21} \mathrm{H}_{16} \mathrm{~N}_{2} \mathrm{O}_{2}$. Anal. Calcd. for $\mathrm{C}_{21} \mathrm{H}_{16} \mathrm{~N}_{2} \mathrm{O}_{2} \cdot 0.25 \mathrm{H}_{2} \mathrm{O}$ : C, 75.77; H, 5.00; N, 8.42. Found: C, 75.96; H, 4.86; N, 8.45.

\section{1-Amino-2-methyl-4-(3-methylphenylamino)anthraquinone} (24)

The compound was synthesized from $500 \mathrm{mg}(1.6 \mathrm{mmol})$ of 9 and $2 \mathrm{ml}$ (1.96 g, $18.29 \mathrm{mmol})$ of 3-methylaniline in the presence of $350 \mathrm{mg}(3.6 \mathrm{mmol})$ of potassium acetate and $30 \mathrm{mg}(0.16 \mathrm{mmol})$ of copper(I) acetate. Reaction time: $24 \mathrm{~h}$.

Yield: $384 \mathrm{mg}(71 \%)$; mp: $255^{\circ} \mathrm{C} .{ }^{1} \mathrm{H}-\mathrm{NMR}$ (DMSO- $d_{6}$, $500 \mathrm{MHz}) \delta(\mathrm{ppm})=2.25\left(\mathrm{~d}, 3 \mathrm{H},{ }^{4} J=0.6 \mathrm{~Hz}, 2-\mathrm{CH}_{3}\right) ; 2.33$ (s, $\left.3 \mathrm{H}, 3^{\prime}-\mathrm{CH}_{3}\right) ; 7.00\left(\mathrm{~d}, 1 \mathrm{H},{ }^{3} J=7.3 \mathrm{~Hz}, \mathrm{C}^{\prime}{ }^{\prime} \mathrm{H}\right.$ or $\left.\mathrm{C}^{\prime} \mathrm{H}\right)$; $7.11\left(\mathrm{~d}, 1 \mathrm{H},{ }^{3} J=7.3 \mathrm{~Hz}, \mathrm{C} 4^{\prime} \mathrm{H}\right.$ or $\left.\mathrm{C}^{\prime} \mathrm{H}\right) ; 7.11\left(\mathrm{~s}, 1 \mathrm{H}, \mathrm{C} 2^{\prime} \mathrm{H}\right)$; $7.31\left(\mathrm{t}, 1 \mathrm{H},{ }^{3} J=7.9 \mathrm{~Hz}, \mathrm{C} 5 \mathrm{H}\right) ; 7.43\left(\mathrm{~d}, 1 \mathrm{H},{ }^{4} J=0.6 \mathrm{~Hz}\right.$, $\mathrm{C} 3 \mathrm{H}) ; 7.80-7.84(\mathrm{~m}, 2 \mathrm{H}, \mathrm{C} 6 \mathrm{H}, \mathrm{C} 7 \mathrm{H}) ; 8.25-8.27(\mathrm{~m}, 2 \mathrm{H}$, $\mathrm{C} 5 \mathrm{H}, \mathrm{C} 8 \mathrm{H}) ; 12.24(\mathrm{~s}, 1 \mathrm{H}, \mathrm{NH}) .{ }^{13} \mathrm{C}-\mathrm{NMR}$ (DMSO- $d_{6}$, $125 \mathrm{MHz}, 303 \mathrm{~K}): \delta(\mathrm{ppm})=18.69\left(2-\mathrm{CH}_{3}\right) ; 21.13\left(3^{\prime}-\right.$ $\left.\mathrm{CH}_{3}\right) ; 108.05,109.48$ (C4a, C9a); $120.32\left(\mathrm{C} 6^{\prime}\right) ; 123.85$ $\left(\mathrm{C} 2^{\prime}\right.$ or $\left.\mathrm{C}^{\prime}\right)$; $124.63(\mathrm{C} 3)$; $125.27\left(\mathrm{C} 2^{\prime}\right.$ or $\left.\mathrm{C}^{\prime}\right)$; 126.00 , 126.13 (C5, C8); 129.59 (C5'); 132.82, 133.00 (C6, C7); 133.99, 134.12 (C8a, C10a); 137.56 (C2); 139.27, 139.37 (C1', C3'); 142.22 (C4); 147.21 (C1); 181.86, 182.01 (C9, C10). EI-MS: $\mathrm{m} / \mathrm{z}(\%)=342.2\left(100 ; \mathrm{C}_{22} \mathrm{H}_{18} \mathrm{~N}_{2} \mathrm{O}_{2}{ }^{+}\right) ; 325.2$ [3; $\left.\left(\mathrm{C}_{22} \mathrm{H}_{8} \mathrm{~N}_{2} \mathrm{O}_{2}-\mathrm{NH}_{3}\right)^{+}\right]$. HRMS $(70 \mathrm{eV}$, EI): Calcd.: 342.1368. Found $342.1367 \Rightarrow \mathrm{C}_{22} \mathrm{H}_{18} \mathrm{~N}_{2} \mathrm{O}_{2}$. Anal. Calcd. for $\mathrm{C}_{22} \mathrm{H}_{18} \mathrm{~N}_{2} \mathrm{O}_{2} \cdot 0.75 \mathrm{H}_{2} \mathrm{O}$ : C, 74.24; $\mathrm{H}, 5.52 ; \mathrm{N}, 7.87$. Found: C, 73.98; H, 5.28; N, 8.16.

\section{1-Amino-2-methyl-4-(4-methylphenylamino)anthraquinone (25) [49]}

The compound was synthesized from $350 \mathrm{mg}(1.1 \mathrm{mmol})$ of 9 and $2.6 \mathrm{~g}(24.3 \mathrm{mmol})$ of 4-methylaniline in the presence of $245 \mathrm{mg}$ (3.6 mmol) of potassium acetate and $21 \mathrm{mg}(0.16 \mathrm{mmol})$ of copper(I) acetate. Reaction time: $5 \mathrm{~h}$.

Yield: $260 \mathrm{mg}(68 \%) .{ }^{1} \mathrm{H}-\mathrm{NMR}$ (DMSO- $\left.d_{6}, 500 \mathrm{MHz}\right) \delta$ $(\mathrm{ppm})=2.24\left(\mathrm{~s}, 3 \mathrm{H}, 2-\mathrm{CH}_{3}\right) ; 2.32\left(\mathrm{~s}, 3 \mathrm{H}, 4^{\prime}-\mathrm{CH}_{3}\right) ; 7.20$ $\left(\mathrm{dm}, 2 \mathrm{H},{ }^{3} \mathrm{~J}=8.5 \mathrm{~Hz}, \mathrm{C} 2^{\prime} \mathrm{H}, \mathrm{C} 6^{\prime} \mathrm{H}\right.$ or $\left.\mathrm{C}^{\prime} \mathrm{H}, \mathrm{C} 5^{\prime} \mathrm{H}\right) ; 7.24$ (dm, $1 \mathrm{H},{ }^{3} \mathrm{~J}=8.2 \mathrm{~Hz}, \mathrm{C} 2^{\prime} \mathrm{H}, \mathrm{C} 6^{\prime} \mathrm{H}$ or $\left.\mathrm{C}^{\prime} \mathrm{H}, \mathrm{C} 5^{\prime} \mathrm{H}\right) ; 7.37$ (s, $1 \mathrm{H}, \mathrm{C} 3 \mathrm{H}) ; 7.80-7.84(\mathrm{~m}, 2 \mathrm{H}, \mathrm{C} 6 \mathrm{H}, \mathrm{C} 7 \mathrm{H}) ; 8.25-8.28$ (m, $2 \mathrm{H}, \mathrm{C} 5 \mathrm{H}, \mathrm{C} 8 \mathrm{H}) ; 12.26$ (s, $1 \mathrm{H}, \mathrm{NH}) .{ }^{13} \mathrm{C}-\mathrm{NMR}$ (DMSO- $d_{6}$, $125 \mathrm{MHz}, 303 \mathrm{~K}): \delta(\mathrm{ppm})=18.69\left(2-\mathrm{CH}_{3}\right) ; 20.65\left(3^{\prime}-\right.$ $\mathrm{CH}_{3}$ ); 107.98, 109.11 (C4a, C9a); 123.70 (2C, $\mathrm{C}^{\prime}, \mathrm{C}^{\prime}$ ); 124.38 (C3); 125.97, 126.12 (C5, C8); 130.30 (2C, C3', C5'); 132.78, 133.91 (C6, C7); 133.99, 134.03, 134.11 (C8a, C10a, C4'); 136.58, 137.64, (C2, C1'); 142.75 (C4); 147.12 (C1); 181.61, 182.94 (C9, C10).

1-Amino-2-methyl-4-(1-naphthylamino)anthraquinone (26)

The compound was synthesized from $400 \mathrm{mg}(1.3 \mathrm{mmol})$ of 9 and $2.5 \mathrm{~g}(17 \mathrm{mmol})$ of 1-aminonaphthalene in the presence of $280 \mathrm{mg}(2.85 \mathrm{mmol})$ of potassium acetate and $25 \mathrm{mg}(0.14 \mathrm{mmol})$ of copper(I) acetate. Reaction time: $12 \mathrm{~h}$. The product is recrystallized from pyridine.

Yield: $123 \mathrm{mg}(20 \%) .{ }^{1} \mathrm{H}-\mathrm{NMR}$ (DMSO- $\left.d_{6}, 500 \mathrm{MHz}\right) \delta$ $(\mathrm{ppm})=2.19\left(\mathrm{~d}, 3 \mathrm{H},{ }^{4} \mathrm{~J}=0.6 \mathrm{~Hz}, 2-\mathrm{CH}_{3}\right) ; 7.27\left(\mathrm{~d}, 1 \mathrm{H},{ }^{4} \mathrm{~J}=\right.$ $0.6 \mathrm{~Hz} \mathrm{C} 3 \mathrm{H}$ ); 7.55-7.62 (m, 4H, naphthalene); 7.82-7.85 $(\mathrm{m}, 3 \mathrm{H}, \mathrm{C} 6 \mathrm{H}, \mathrm{C} 7 \mathrm{H}$, naphthalene); $8.02(\mathrm{~m}, 1 \mathrm{H}$, naphtha- 
lene); 8.07 (m, $1 \mathrm{H}$, naphthalene); 8.31 (m, 2H, C5H, C8H); $12.74(\mathrm{~s}, 1 \mathrm{H}, \mathrm{NH}) \cdot{ }^{13} \mathrm{C}-\mathrm{NMR}$ (DMSO- $\left.d_{6}, 125 \mathrm{MHz}\right): \delta$ $(\mathrm{ppm})=18.63\left(2-\mathrm{CH}_{3}\right) ; 108.00,109.61(\mathrm{C} 4 \mathrm{a} . \mathrm{C} 9 \mathrm{a}) ; 121.35$, 121.95 (C2', C4'); 124.67 (C3); 125.45, 126.10, 126.19, 126.27, 126.82, 127.00, 128.63, 128.81 (C5, C8, C5', C6', $\left.\mathrm{C}^{\prime}, \mathrm{C} 8^{\prime}, \mathrm{C} 4 \mathrm{a}^{\prime}, \mathrm{C} 8 \mathrm{a}^{\prime}\right)$; 132.84, 133.09, 134.01, 134.22, 134.45, 135.16 (C6, C7, C8a, C10a, C1', C3'); 137.76 (C2); 143.48 (C4); 147.24 (C1); 181.99, 182.27 (C9, C10). EIMS: $\mathrm{m} / \mathrm{z}(\%)=378.2\left(100 ; \mathrm{C}_{25} \mathrm{H}_{18} \mathrm{~N}_{2} \mathrm{O}_{2}{ }^{+}\right)$. HRMS $(70 \mathrm{eV}$, EI): Calcd.: 378.1368. Found 378.1365 $\Rightarrow \mathrm{C}_{25} \mathrm{H}_{18} \mathrm{~N}_{2} \mathrm{O}_{2}$.

Synthesis of the sulfonic acid chloride of bromaminic acid (10) $[50]$

Bromaminic acid sodium salt $(\mathbf{8}, 10 \mathrm{~g}$, ca. $25 \mathrm{mmol})$ was suspended in $100 \mathrm{ml}$ of phosphorus oxychloride $\left(\mathrm{POCl}_{3}\right)$ and phosphorus pentachloride $\left(\mathrm{PCl}_{5}, 9 \mathrm{~g}, 43 \mathrm{mmol}\right.$ ) was added. The reaction mixture was stirred at $95^{\circ} \mathrm{C}$ under argon for $6 \mathrm{~h}$. The remaining $\mathrm{POCl}_{3}$ was distilled off under reduced pressure. Two different methods have been used to isolate the product: (1) the residue was cooled in an ice bath and the cold mixture was poured into $200 \mathrm{ml}$ of ice water. The precipitated solid was filtered off and dried under vacuum and stored until use; (2) the residue was taken up in dichloromethane and the resulting solution was washed three times with $40 \mathrm{ml}$ of ice water each. The organic phase was dried over anhydrous magnesium sulfate and after filtration, the solvent was distilled off under vacuum. The residue obtained was dried and used in the next step without further purification. Yield: 90-96\% (raw product); $\mathrm{mp}$ approximately $190^{\circ} \mathrm{C}$ (decomposition).

\section{1-Amino-4-bromoanthraquinone-2-sulfonic acid methyl ester (27)}

The sulfonic acid chloride $10(250 \mathrm{mg}, 0.6 \mathrm{mmol})$ was suspended in $50 \mathrm{ml}$ of methanol, and sodium methoxide (approximately $500 \mathrm{mg}$ ) was added. The reaction mixture was stirred under an argon atmosphere for $16 \mathrm{~h}$ at RT and subsequently evaporated to dryness. The residue was suspended in a mixture of cyclohexane and ethyl acetate (37:3), silica gel (5 g) was added, and the solvent was removed by rotary evaporation. The material absorbed on silica gel was put onto a silica gel column and the product was purified by column chromatography using cyclohexane:ethyl acetate (37:3) as eluent.

Yield: $143 \mathrm{mg}(58 \%) ;{ }^{1} \mathrm{H}-\mathrm{NMR}$ (DMSO- $d_{6}, 500 \mathrm{MHz}$, $303 \mathrm{~K}): \delta(\mathrm{ppm})=3.97\left(\mathrm{~s}, 3 \mathrm{H}, \mathrm{OCH}_{3}\right) ; 7.52\left(\mathrm{br}, 1 \mathrm{H}, \mathrm{NH}_{2}\right)$; $7.83\left(\mathrm{td}, 1 \mathrm{H},{ }^{3} J=7.4 \mathrm{~Hz},{ }^{4} J=1.6 \mathrm{~Hz}, \mathrm{C} 6 \mathrm{H}\right.$ or $\left.\mathrm{C} 7 \mathrm{H}\right) ; 7.87$ (td, $1 \mathrm{H},{ }^{3} J=7.4 \mathrm{~Hz},{ }^{4} J=1.7 \mathrm{~Hz}, \mathrm{C} 6 \mathrm{H}$ or $\left.\mathrm{C} 7 \mathrm{H}\right) ; 8.04(\mathrm{~s}, 1 \mathrm{H}$, $\mathrm{C} 3 \mathrm{H}) ; 8.09$ (dd, $1 \mathrm{H},{ }^{3} J=7.6 \mathrm{~Hz},{ }^{4} J=1.3 \mathrm{~Hz}, \mathrm{C} 5 \mathrm{H}$ or $\mathrm{C} 8 \mathrm{H}$ ); $8.16\left(\mathrm{dd}, 1 \mathrm{H},{ }^{3} \mathrm{~J}=7.6 \mathrm{~Hz},{ }^{4} \mathrm{~J}=1.3 \mathrm{~Hz}, \mathrm{C} 5 \mathrm{H}\right.$ or $\left.\mathrm{C} 8 \mathrm{H}\right) ; 9.56$ (br, $1 \mathrm{H}, \mathrm{NH}_{2}$ ). ${ }^{13} \mathrm{C}-\mathrm{NMR}$ (DMSO- $d_{6}, 125 \mathrm{MHz}, 303 \mathrm{~K}$ ): $\delta$
$(\mathrm{ppm})=62.24\left(\mathrm{OCH}_{3}\right) ; 106.21,114.79(\mathrm{C} 4 \mathrm{a}, \mathrm{C} 9 \mathrm{a}) ; 126.17$, 126.46 (C5, C8); 131.40 (C4); 133.10, 133.68, 133.76, 134.31 (C6, C7, C8a, C10a); 138.63, 138.93 (C2, C3); 148.4 (C1); 182.16, 183.70 (C9, C10).

General procedure for the synthesis of 1-amino-4-bromoanthraquinone-2-sulfonic acid nitrophenyl esters

The sulfonic acid chloride $\mathbf{1 0}(285 \mathrm{mg}, 0.7 \mathrm{mmol})$ was suspended in $33 \mathrm{ml}$ of freshly distilled dichloromethane and completely dissolved by stirring it under an argon atmosphere for $30 \mathrm{~min}$. Then a solution of $430 \mathrm{mg}(3.1 \mathrm{mmol})$ of the appropriate nitrophenol and $4 \mathrm{ml}$ of triethylamine in $8 \mathrm{ml}$ of dichloromethane were added (producing white fumes). The reaction mixture was stirred until the starting compound $\mathbf{1 0}$ had completely disappeared (TLC control). The solvent was evaporated and the residue was dissolved in $10 \mathrm{ml}$ of a mixture of dichloromethane and cyclohexane (7:2). Subsequent column chromatography on silica gel using the same solvent mixture gave the pure products.

\section{1-Amino-4-bromoanthraquinone-2-sulfonic acid 2-nitrophenyl ester (28)}

Yield: $96 \mathrm{mg}(27 \%)$; mp $213-214^{\circ} \mathrm{C} .{ }^{1} \mathrm{H}-\mathrm{NMR}$ (DMSO$\left.d_{6}, 303 \mathrm{~K}, 500 \mathrm{MHz}\right): \delta(\mathrm{ppm})=7.32\left(\mathrm{dd}, 1 \mathrm{H},{ }^{3} J=8.3 \mathrm{~Hz}\right.$, $\left.{ }^{4} J=1.2 \mathrm{~Hz}, \mathrm{C} 6{ }^{\prime} \mathrm{H}\right) ; 7.63$ (ddd, $1 \mathrm{H},{ }^{3} J=8.2 \mathrm{~Hz},{ }^{3} J=7.6 \mathrm{~Hz}$, $\left.{ }^{4} J=1.3 \mathrm{~Hz}, \mathrm{C} 5{ }^{\prime} \mathrm{H}\right) ; 7.74\left(\mathrm{ddd},{ }^{3} J=8.2 \mathrm{~Hz},{ }^{3} J=7.6 \mathrm{~Hz},{ }^{4} J=\right.$ $\left.1.6 \mathrm{~Hz}, \mathrm{C} 4{ }^{\prime} \mathrm{H}\right) ; 7.89$ (s, $\left.1 \mathrm{H}, \mathrm{C} 3 \mathrm{H}\right) ; 7.91\left(\mathrm{td}, 1 \mathrm{H},{ }^{3} J=7.3 \mathrm{~Hz}\right.$, ${ }^{4} J=1.7 \mathrm{~Hz}, \mathrm{C} 6 \mathrm{H}$ or $\left.\mathrm{C} 7 \mathrm{H}\right) ; 7.94\left(\mathrm{td}, 1 \mathrm{H},{ }^{3} J=7.4 \mathrm{~Hz},{ }^{4} J=\right.$ $1.8 \mathrm{~Hz}, \mathrm{C} 6 \mathrm{H}$ or $\mathrm{C} 7 \mathrm{H}) ; 8.10\left(\mathrm{ddm}, 1 \mathrm{H},{ }^{3} J=7.1 \mathrm{~Hz},{ }^{4} J=\right.$ $1.8 \mathrm{~Hz}, \mathrm{C} 5 \mathrm{H}$ or $\mathrm{C} 8 \mathrm{H}) ; 8.14\left(\mathrm{dd}, 1 \mathrm{H},{ }^{3} J=8.0 \mathrm{~Hz},{ }^{4} J=1.7 \mathrm{~Hz}\right.$, $\left.\mathrm{C}^{\prime} \mathrm{H}\right) ; 8.20\left(\mathrm{ddm}, 1 \mathrm{H},{ }^{3} J=7.1 \mathrm{~Hz},{ }^{4} J=1.8 \mathrm{~Hz}, \mathrm{C} 5 \mathrm{H}\right.$ or $\mathrm{C} 8 \mathrm{H}) .{ }^{13} \mathrm{C}-\mathrm{NMR}\left(\mathrm{DMSO}-d_{6}, 125 \mathrm{MHz}, 303 \mathrm{~K}\right): \delta(\mathrm{ppm})=$ 104.08 (C9a); 118.13 (C4a); 120.62 (C4); 124.87 (C3' or $\left.\mathrm{C}^{\prime}\right)$; 126.48, 126.58 (C5, C8); 126.60 (C3' or $\left.\mathrm{C}^{\prime}\right)$; 129.44 (C4'); 132.85, 133.62, 134.54, 134.84 (C6, C7, C8a, C10a); 135.65 (C5'); 137.62 (C2); 139.95 (C2'); 142.23 (C3); 142.90 (C1'); 148.21 (C1); 182.15, 184.42 (C9 und C10). EI-MS: $\mathrm{m} / \mathrm{z}(\%)=502.0+504.0$ (ratio $1: 1 ; 100$; $\left[\mathrm{C}_{20} \mathrm{H}_{11} \mathrm{BrN}_{2} \mathrm{O}_{7} \mathrm{~S}\right]^{++}$); 380.9+382.9 (ratio $1: 1 ; 31$; $\left[\mathrm{C}_{14} \mathrm{H}_{8} \mathrm{BrNO}_{5} \mathrm{~S}\right]^{+\cdot}$ ); $300.0+301.9$ (ratio $1: 1 ; 84$; $\left.\left[\mathrm{C}_{14} \mathrm{H}_{7} \mathrm{BrNO}_{2}\right]^{+}\right) ; 221.1\left(41 ;\left[\mathrm{C}_{14} \mathrm{H}_{7} \mathrm{NO}_{2}\right]^{+\cdot}\right)$. HRMS (70 eV, EI): Calcd:: 501.9470. Found: $501.9471 \Rightarrow$ $\mathrm{C}_{20} \mathrm{H}_{11} \mathrm{BrN}_{2} \mathrm{O}_{7} \mathrm{~S}$. Anal. Calcd. for $\mathrm{C}_{20} \mathrm{H}_{11} \mathrm{BrN}_{2} \mathrm{O}_{7} \mathrm{~S}$ : C, 47.73; H, 2.20; N, 5.57. Found: C, 47.81; H, 2.26; N, 5.52

\section{1-Amino-4-bromoanthraquinone-2-sulfonic acid}

3-nitrophenyl ester (29)

Yield: $215 \mathrm{mg}(61 \%) ; \mathrm{mp} 189^{\circ} \mathrm{C} .{ }^{1} \mathrm{H}-\mathrm{NMR}$ (DMSO- $d_{6}, 303$ $\mathrm{K}, 500 \mathrm{MHz}): \delta(\mathrm{ppm})=7.65\left(\mathrm{ddd}, 1 \mathrm{H},{ }^{3} J=8.2 \mathrm{~Hz},{ }^{4} J=\right.$ 
$\left.2.4 \mathrm{~Hz},{ }^{5} J=1.1 \mathrm{~Hz}, \mathrm{C} 6{ }^{\prime} \mathrm{H}\right) ; 7.71\left(\mathrm{t}, 1 \mathrm{H},{ }^{3} J=8.3 \mathrm{~Hz}, \mathrm{C} 5^{\prime} \mathrm{H}\right)$; $7.89\left(\mathrm{td}, 1 \mathrm{H},{ }^{3} J=7.3 \mathrm{~Hz},{ }^{4} J=1.7 \mathrm{~Hz}, \mathrm{C} 6 \mathrm{H}\right.$ or $\left.\mathrm{C} 7 \mathrm{H}\right) ; 7.92(\mathrm{td}$, $1 \mathrm{H},{ }^{3} J=7.4 \mathrm{~Hz},{ }^{4} J=1.7 \mathrm{~Hz}, \mathrm{C} 6 \mathrm{H}$ or $\left.\mathrm{C} 7 \mathrm{H}\right) ; 8.01(\mathrm{~s}, 1 \mathrm{H}$, $\mathrm{C} 3 \mathrm{H}) ; 8.07$ (ddm, $1 \mathrm{H},{ }^{3} J=7.0 \mathrm{~Hz},{ }^{4} J=2.0 \mathrm{~Hz}, \mathrm{C} 5 \mathrm{H}$ or $\left.\mathrm{C} 8 \mathrm{H}\right)$; $8.10\left(\mathrm{t},{ }^{4} J=2.4 \mathrm{~Hz}, \mathrm{C} 2{ }^{\prime} \mathrm{H}\right) ; 8.16\left(\mathrm{ddm}, 1 \mathrm{H},{ }^{3} J=7.6 \mathrm{~Hz},{ }^{4} J=\right.$ $1.6 \mathrm{~Hz}, \mathrm{C} 5 \mathrm{H}$ or $\mathrm{C} 8 \mathrm{H}) ; 8.22\left(\mathrm{ddd}, 1 \mathrm{H},{ }^{3} J=8.2 \mathrm{~Hz},{ }^{4} J=2.1 \mathrm{~Hz}\right.$, $\left.{ }^{5} J=1.1 \mathrm{~Hz}, \mathrm{C} 4{ }^{\prime} \mathrm{H}\right) .{ }^{13} \mathrm{C}-\mathrm{NMR}$ (DMSO- $d_{6}, 125 \mathrm{MHz}, 303 \mathrm{~K}$ ): $\delta(\mathrm{ppm})=104.28(\mathrm{C} 9 \mathrm{a}) ; 117.78\left(\mathrm{C}^{\prime}\right) ; 117.88(\mathrm{C} 4 \mathrm{a}) ; 120.72$ (C4); 123.15 (C4'); 126.44, 126.57 (C5, C8); 128.83 (C6'); 131.94 (C5'); 132.83, 133.21, 134.50, 134.78 (C6, C7, C8a, C10a); 137.44 (C2); 142.54 (C3); 148.11 (C1); 148.32, 148.67 (C1', C3'); 182.03, 184.40 (C9, C10). EI-MS: m/z $(\%)=502.0+504.0\left(\right.$ ratio $\left.1: 1 ; 46 ;\left[\mathrm{C}_{20} \mathrm{H}_{11} \mathrm{BrN}_{2} \mathrm{O}_{7} \mathrm{~S}\right]^{+}\right) ; 424$ (84; $\left[\mathrm{C}_{20} \mathrm{H}_{11} \mathrm{~N}_{2} \mathrm{O}_{7} \mathrm{~S}\right]^{+\cdot}$ ); 300.0+301.9 (ratio 1:1; 45; $\left.\left[\mathrm{C}_{14} \mathrm{H}_{7} \mathrm{BrNO}_{2}\right]^{+}\right) ; 286\left(49 ;\left[\mathrm{C}_{14} \mathrm{H}_{8} \mathrm{NO}_{4} \mathrm{~S}\right]^{+}\right) ; 238.0(61 ;$ $\left.\left[\mathrm{C}_{14} \mathrm{H}_{8} \mathrm{NO}_{3}\right]^{+}\right) ; 222.0\left(100 ;\left[\mathrm{C}_{14} \mathrm{H}_{7} \mathrm{NO}_{2}\right]^{+}\right)$. HRMS $(70 \mathrm{eV}$, EI): Calcd.: 501.9470. Found: $501.9469 \Rightarrow \mathrm{C}_{20} \mathrm{H}_{11} \mathrm{BrN}_{2} \mathrm{O}_{7} \mathrm{~S}$. Anal. Calcd. for $\mathrm{C}_{20} \mathrm{H}_{11} \mathrm{BrN}_{2} \mathrm{O}_{7} \mathrm{~S}: \mathrm{C}, 47.73 ; \mathrm{H}, 2.20 ; \mathrm{N}$, 5.57. Found: C, 50.98; H, 2.29; N, 5.88.

\section{1-Amino-4-bromoanthraquinone-2-sulfonic acid 4-nitrophenyl ester (30)}

Yield: $266 \mathrm{mg}$ (76\%); mp $196^{\circ} \mathrm{C} .{ }^{1} \mathrm{H}-\mathrm{NMR}$ (DMSO- $d_{6}, 303$ $\mathrm{K}, 500 \mathrm{MHz}): \delta(\mathrm{ppm})=7.49\left(\mathrm{dm}, 2 \mathrm{H},{ }^{3} \mathrm{~J}=9.2 \mathrm{~Hz}, \mathrm{C} 2{ }^{\prime} \mathrm{H}\right.$, C6'H); 7.89 (td, $1 \mathrm{H},{ }^{3} J=7.4 \mathrm{~Hz},{ }^{4} J=1.6 \mathrm{~Hz}, \mathrm{C} 6 \mathrm{H}$ or $\left.\mathrm{C} 7 \mathrm{H}\right)$; $7.92\left(\mathrm{td}, 1 \mathrm{H},{ }^{3} J=7.4 \mathrm{~Hz},{ }^{4} J=1.8 \mathrm{~Hz}, \mathrm{C} 6 \mathrm{H}\right.$ or $\mathrm{C} 7 \mathrm{H}$ ); 7.98 (s, $1 \mathrm{H}, \mathrm{C} 3 \mathrm{H}) ; 8.08\left(\mathrm{ddm}, 1 \mathrm{H},{ }^{3} J=7.4 \mathrm{~Hz},{ }^{4} J=1.6 \mathrm{~Hz}, \mathrm{C} 5 \mathrm{H}\right.$ or $\mathrm{C} 8 \mathrm{H}) ; 8.17\left(\mathrm{ddm}, 1 \mathrm{H},{ }^{3} J=7.4 \mathrm{~Hz},{ }^{4} J=1.3 \mathrm{~Hz}, \mathrm{C} 5 \mathrm{H}\right.$ or $\mathrm{C} 8 \mathrm{H}) ; 8.26\left(\mathrm{dm}, 2 \mathrm{H},{ }^{3} J=9.2 \mathrm{~Hz}, \mathrm{C}^{\prime} \mathrm{H}, \mathrm{C}^{\prime} \mathrm{H}\right) .{ }^{13} \mathrm{C}-\mathrm{NMR}$ $\left(\mathrm{DMSO} d_{6}, 125 \mathrm{MHz}, 303 \mathrm{~K}\right): \delta(\mathrm{ppm})=104.27$ (C9a); 117.96 (C4a); 120.81 (C4); 123.54 (2C, C2', C6'); 126.19 (2C, C3', C5'); 126.45, 126.58 (C5, C8); 132.85, 133.23, 134.51, 134.79 (C6, C7, C8a, C10a); 137.47 (C2); 142.42 (C3); 146.61 (C4'); 148.03 (C1); 152.65 (C1'); 182.06, 184.44 (C9 und C10). EI-MS: $\mathrm{m} / \mathrm{z}(\%)=502.0+504.0$ (ratio 1:1; 30; $\left.\left[\mathrm{C}_{20} \mathrm{H}_{11} \mathrm{BrN}_{2} \mathrm{O}_{7} \mathrm{~S}\right]^{+-}\right) ; 424\left(84 ;\left[\mathrm{C}_{20} \mathrm{H}_{11} \mathrm{~N}_{2} \mathrm{O}_{7} \mathrm{~S}\right]^{++}\right)$; 300.0+301.9 (ratio 1:1; 18; $\left[\mathrm{C}_{14} \mathrm{H}_{7} \mathrm{BrNO}_{2}\right]^{+}$); 286 (52; $\left.\left[\mathrm{C}_{14} \mathrm{H}_{8} \mathrm{NO}_{4} \mathrm{~S}\right]^{+}\right) ; 238.0\left(61 ;\left[\mathrm{C}_{14} \mathrm{H}_{8} \mathrm{NO}_{3}\right]^{+}\right) ; 222.0(100$; $\left.\left[\mathrm{C}_{14} \mathrm{H}_{7} \mathrm{NO}_{2}\right]^{+}\right)$. HRMS (70 eV, EI): Calcd.: 501.9470. Found: $501.9472 \Rightarrow \mathrm{C}_{20} \mathrm{H}_{11} \mathrm{BrN}_{2} \mathrm{O}_{7} \mathrm{~S}$. Anal. Calcd. for $\mathrm{C}_{20} \mathrm{H}_{11} \mathrm{BrN}_{2} \mathrm{O}_{7} \mathrm{~S}: \mathrm{C}, 47.73 ; \mathrm{H}, 2.20 ; \mathrm{N}, 5.57$. Found: C, 47.55; H, 2.20; N, 5.52.

General procedure for the synthesis of bromaminic acid amides (sulfonamides 31-33)

The sulfonic acid chloride $\mathbf{1 0}$ was put into a round-bottom flask flushed with argon and freshly dried and distilled dichloromethane or acetone, respectively, was added. The appropriate amine dissolved in a mixture of triethylamine and dichloromethane was added to the suspension resulting in the evolvement of white fumes. The reaction mixture was stirred at RT under an argon atmosphere until starting compound $\mathbf{1 0}$ had completely disappeared [TLC monitoring on silica gel using cyclohexane:ethyl acetate (17:3) as an eluent]. Then the solvent was distilled off under reduced pressure and the residue was dissolved in a mixture of dichloromethane:cyclohexane:ethyl acetate (40:51:9 or $10: 17: 3$, respectively) or in dichloromethane:cyclohexane (7:3), respectively, and purified by column chromatography on silica gel using the same solvent mixture.

\section{1-Amino-4-bromoanthraquinone-2-sulfonic acid phenyl amide (31) [49]}

The compound was prepared from $0.5 \mathrm{~g}(1.25 \mathrm{mmol})$ of $\mathbf{1 0}$ in $30 \mathrm{ml}$ of dichloromethane and $1.5 \mathrm{ml}(1.53 \mathrm{~g}, 16.5 \mathrm{mmol})$ of freshly distilled aniline in $10 \mathrm{ml}$ of dichloromethane. Reaction time: $16 \mathrm{~h}$ at RT; purification by column chromatography with dichloromethane:cyclohexane:ethyl acetate $(10: 17: 3)$ as eluent. Upon evaporation of the product-containing fractions an orange-red colored product precipitated, which was collected by filtration and dried.

Yield: $200 \mathrm{mg}$ (18\%); $\mathrm{mp} 214^{\circ} \mathrm{C}$ (lit. $\mathrm{mp} 220^{\circ} \mathrm{C}$ [48]). ${ }^{1} \mathrm{H}-\mathrm{NMR}\left(\mathrm{DMSO}-d_{6}, 500 \mathrm{MHz}, 303 \mathrm{~K}\right): \delta(\mathrm{ppm})=7.08$ (tt, $\left.{ }^{3} J=7.4 \mathrm{~Hz}, \mathrm{C} 4^{\prime} \mathrm{H}\right) ; 7.11\left(\mathrm{~m}, 2 \mathrm{H}, \mathrm{C} 2^{\prime} \mathrm{H}, \mathrm{C} 6^{\prime} \mathrm{H}\right) ; 7.28$ (m, 2H, $\left.\mathrm{C}^{\prime}{ }^{\prime} \mathrm{H}, \mathrm{C}^{\prime} \mathrm{H}\right) ; 7.81\left(\mathrm{td}, 1 \mathrm{H},{ }^{3} J=7.3 \mathrm{~Hz},{ }^{4} J=1.7 \mathrm{~Hz}, \mathrm{C} 6 \mathrm{H}\right.$ or $\mathrm{C} 7 \mathrm{H}) ; 7.84\left(\mathrm{td}, 1 \mathrm{H},{ }^{3} J=7.4 \mathrm{~Hz},{ }^{4} J=1.7 \mathrm{~Hz}, \mathrm{C} 6 \mathrm{H}\right.$ or $\left.\mathrm{C} 7 \mathrm{H}\right)$; $8.00\left(\mathrm{dd}, 1 \mathrm{H},{ }^{3} J=7.1 \mathrm{~Hz},{ }^{4} J=1.8 \mathrm{~Hz}, \mathrm{C} 5 \mathrm{H}\right.$ or $\left.\mathrm{C} 8 \mathrm{H}\right) ; 8.08$ (s, $1 \mathrm{H}, \mathrm{C} 3 \mathrm{H}) ; 8.09\left(\mathrm{dd}, 1 \mathrm{H},{ }^{3} J=7.6 \mathrm{~Hz},{ }^{4} J=1.6 \mathrm{~Hz}, \mathrm{C} 5 \mathrm{H}\right.$ or $\mathrm{C} 8 \mathrm{H}) ; 10.81$ (s, $1 \mathrm{H}, \mathrm{NH}) .{ }^{13} \mathrm{C}-\mathrm{NMR}$ (DMSO- $d_{6}, 125 \mathrm{MHz}$, $303 \mathrm{~K}): \delta(\mathrm{ppm})=104.67(\mathrm{C} 9 \mathrm{a}) ; 116.82(\mathrm{C} 4 \mathrm{a}) ; 120.68(2 \mathrm{C}$, C2', C6'); 125.13 (C4'); 126.26, 126.44 (C5, C8); 126.98 (C4); 129.65 (2C, C3', C5'); 132.86, 133.30 (C8a, C10a); 134.18, 134.50, 135.33 (C3, C6, C7); 136.51 (C1'); 141.88 (C2); 147.50 (C1); 181.95, 184.28 (C9, C10).

\section{1-Amino-4-bromoanthraquinone-2-sulfonic acid benzylamide (32)}

The compound was prepared from $0.5 \mathrm{~g}(1.25 \mathrm{mmol})$ of $\mathbf{1 0}$ in $20 \mathrm{ml}$ of dichloromethane, and $0.3 \mathrm{ml}(0.29 \mathrm{~g}$, $2.75 \mathrm{mmol}$ ) of benzylamine and $0.3 \mathrm{ml}$ of triethylamine in $30 \mathrm{ml}$ of dichloromethane. Reaction time: $16 \mathrm{~h}$ at RT; purification by column chromatography with dichloromethane:cyclohexane:ethyl acetate (40:51:9) as eluent.

Yield: $215 \mathrm{mg}(37 \%) ; \mathrm{mp} 189^{\circ} \mathrm{C} .{ }^{1} \mathrm{H}-\mathrm{NMR}$ (DMSO- $d_{6}$, $303 \mathrm{~K}, 500 \mathrm{MHz}): \delta(\mathrm{ppm})=4.12\left(\mathrm{~s}, 2 \mathrm{H}, \mathrm{CH}_{2}\right) ; 7.02\left(\mathrm{t},{ }^{3} \mathrm{~J}=\right.$ $\left.7.2 \mathrm{~Hz}, \mathrm{C} 4{ }^{\prime} \mathrm{H}\right) ; 7.14$ (t, $\left.2 \mathrm{H},{ }^{3} \mathrm{~J}=7.7 \mathrm{~Hz} \mathrm{C} 3^{\prime} \mathrm{H}, \mathrm{C} 5^{\prime} \mathrm{H}\right) ; 7.18$ (d, $\left.2 \mathrm{H},{ }^{3} J=6.8 \mathrm{~Hz} \mathrm{C} 2{ }^{\prime} \mathrm{H}, \mathrm{C} 6{ }^{\prime} \mathrm{H}\right) ; 7.87\left(\mathrm{td}, 1 \mathrm{H},{ }^{3} \mathrm{~J}=7.2 \mathrm{~Hz}\right.$, ${ }^{4} J=1.4 \mathrm{~Hz}, \mathrm{C} 6 \mathrm{H}$ or $\left.\mathrm{C} 7 \mathrm{H}\right) ; 7.90\left(\mathrm{td}, 1 \mathrm{H},{ }^{3} J=7.4 \mathrm{~Hz},{ }^{4} J=\right.$ $1.7 \mathrm{~Hz}, \mathrm{C} 6 \mathrm{H}$ or $\mathrm{C} 7 \mathrm{H}) ; 8.02$ (s, $1 \mathrm{H}, \mathrm{C} 3 \mathrm{H}) ; 8.07$ (dd, $1 \mathrm{H},{ }^{3} \mathrm{~J}=$ $7.4 \mathrm{~Hz},{ }^{4} J=1.8 \mathrm{~Hz}, \mathrm{C} 5 \mathrm{H}$ or $\left.\mathrm{C} 8 \mathrm{H}\right) ; 8.14$ (dd, $1 \mathrm{H},{ }^{3} J=7.5 \mathrm{~Hz}$, ${ }^{4} J=1.4 \mathrm{~Hz}, \mathrm{C} 5 \mathrm{H}$ or $\left.\mathrm{C} 8 \mathrm{H}\right) ; 8.81(\mathrm{~s}, 1 \mathrm{H}, \mathrm{NH}) .{ }^{13} \mathrm{C}-\mathrm{NMR}$ $\left(\right.$ DMSO- $\left.d_{6}, 125 \mathrm{MHz}, 303 \mathrm{~K}\right): \delta(\mathrm{ppm})=46.06\left(\mathrm{CH}_{2}\right) ; 105.19$ 
(C9a); 116.41 (C4a); 126.30, 126.51 (C5, C8); 127.23 (C4'); 127.72, 128.18 (C2', C6', C3', C5'); 128.96 (C4); 132.83, 133.37 (C8a, C10a); 134.22, 134.62, 134.63 (C3, C6, C7); 136.69 (C1'); 141.51 (C2); 147.39 (C1); 182.07, 184.08 (C9, C10). EI-MS: $\mathrm{m} / \mathrm{z}(\%)=471.9+469.9$ (ratio $1: 1 ; 8$; $\left.\left[\mathrm{C}_{21} \mathrm{H}_{15} \mathrm{BrN}_{2} \mathrm{O}_{4} \mathrm{~S}\right]^{+}\right) ; 392.0\left(5 ; \quad\left[\mathrm{C}_{21} \mathrm{H}_{15} \quad \mathrm{~N}_{2} \mathrm{O}_{4} \mathrm{~S}\right]^{++}\right) ; 300.9$ +303 (ratio $1: 1 ; 27 ;\left[\mathrm{C}_{14} \mathrm{H}_{7} \mathrm{BrNO}_{2}\right]^{+}$); 223.1 (29; $\left.\left[\mathrm{C}_{14} \mathrm{H}_{7} \mathrm{NO}_{2}\right]^{++}\right) ; 106.1\left(100 ;\left[\mathrm{C}_{7} \mathrm{H}_{8} \mathrm{~N}\right]^{+}\right)$. HRMS (70 eV, EI): Calcd.: 469.993. Found: $469.992 \Rightarrow \mathrm{C}_{21} \mathrm{H}_{15} \mathrm{BrN}_{2} \mathrm{O}_{4} \mathrm{~S}$. Anal. Calcd. for $\mathrm{C}_{21} \mathrm{H}_{15} \mathrm{BrN}_{2} \mathrm{O}_{4} \mathrm{~S} \cdot 1.5 \mathrm{C}_{6} \mathrm{H}_{12}: \mathrm{C}, 60.30 ; \mathrm{H}, 5.57 ; \mathrm{N}$, 4.69. Found: C, 60.17; H, 5.21; N, 4.88 .

\section{1-Amino-4-bromoanthraquinone-2-sulfonic acid phenethylamide (33)}

The compound was prepared from $0.5 \mathrm{~g}(1.25 \mathrm{mmol})$ of $\mathbf{1 0}$ in $10 \mathrm{ml}$ of dichloromethane, and $0.3 \mathrm{ml}(0.29 \mathrm{~g}, 2.4 \mathrm{mmol})$ of 2-phenethylamine and $0.3 \mathrm{ml}$ of triethylamine in $30 \mathrm{ml}$ of dichloromethane. Reaction time: $16 \mathrm{~h}$ at RT; purification by column chromatography with dichloromethane:cyclohexane:ethyl acetate (40:51:9) as eluent.

Yield: $296 \mathrm{mg}$ (48\%); mp $176^{\circ} \mathrm{C} .{ }^{1} \mathrm{H}-\mathrm{NMR}$ (DMSO- $d_{6}$, $303 \mathrm{~K}, 500 \mathrm{MHz}): \delta(\mathrm{ppm})=2.68\left(\mathrm{t}, 2 \mathrm{H},{ }^{3} J=7.1 \mathrm{~Hz}, \mathrm{ArCH}_{2}\right)$; $3.15\left(\mathrm{t}, 2 \mathrm{H},{ }^{3} \mathrm{~J}=7.1 \mathrm{~Hz}, \mathrm{NHCH}_{2}\right) ; 7.00\left(\mathrm{tt},{ }^{3} \mathrm{~J}=6.8 \mathrm{~Hz},{ }^{4} \mathrm{~J}=\right.$ $\left.1.9 \mathrm{~Hz}, \mathrm{C} 4{ }^{\prime} \mathrm{H}\right)$; 7.10-7.16 (m, 4H, C2' $\left.\mathrm{H}, \mathrm{C}^{\prime} \mathrm{H}, \mathrm{C} 5^{\prime} \mathrm{H}, \mathrm{C} 6^{\prime} \mathrm{H}\right)$; 7.87 (td, $1 \mathrm{H},{ }^{3} J=7.2 \mathrm{~Hz},{ }^{4} J=1.4 \mathrm{~Hz}, \mathrm{C} 6 \mathrm{H}$ or $\left.\mathrm{C} 7 \mathrm{H}\right) ; 7.90$ (td, $1 \mathrm{H},{ }^{3} J=7.3 \mathrm{~Hz},{ }^{4} J=1.7 \mathrm{~Hz}, \mathrm{C} 6 \mathrm{H}$ or $\left.\mathrm{C} 7 \mathrm{H}\right) ; 8.08$ (ddd, $1 \mathrm{H}$, ${ }^{3} J=7.3 \mathrm{~Hz},{ }^{4} J=1.7 \mathrm{~Hz},{ }^{5} J=0.4 \mathrm{~Hz}, \mathrm{C} 5 \mathrm{H}$ or $\left.\mathrm{C} 8 \mathrm{H}\right) ; 8.09$ (s, $1 \mathrm{H}, \mathrm{C} 3 \mathrm{H}$ ); 8.16 (ddd, $1 \mathrm{H},{ }^{3} J=7.3 \mathrm{~Hz},{ }^{4} J=1.6 \mathrm{~Hz},{ }^{5} J=0.3 \mathrm{~Hz}$, $\mathrm{C} 5 \mathrm{H}$ or $\mathrm{C} 8 \mathrm{H}) ; 8.33$ (s, $1 \mathrm{H}, \mathrm{NH}) .{ }^{13} \mathrm{C}-\mathrm{NMR}$ (DMSO- $d_{6}$, $125 \mathrm{MHz}, 303 \mathrm{~K}): \delta(\mathrm{ppm})=35.29\left(\mathrm{ArCH}_{2}\right) ; 43.86$ $\left(\mathrm{NHCH}_{2}\right) ; 105.09(\mathrm{C} 9 \mathrm{a}) ; 116.67(\mathrm{C} 4 \mathrm{a}) ; 126.23,126.31$, 126.51 (C5, C8, C4'); 128.23 (2C, C2', $\mathrm{C} 6^{\prime}$ or $\mathrm{C}^{\prime}, \mathrm{C}^{\prime}$ ); 128.69 (C4); 128.76 (2C, C2', $\mathrm{C}^{\prime}$ or $\left.\mathrm{C}^{\prime}, \mathrm{C}^{\prime}\right)$; 132.90 , 133.45 (C8a, C10a); 134.21, 134.60, 134.78 (C3, C6, C7); 138.49 (C1'); 141.24 (C2); 147.45 (C1); 182.15, 184.22 (C9, C10). EI-MS: $\mathrm{m} / \mathrm{z}(\%)=484.0+486.0$ (ratio $1: 1 ; 21$; $\left[\mathrm{C}_{22} \mathrm{H}_{17} \mathrm{BrN}_{2} \mathrm{O}_{4} \mathrm{~S}\right]^{+\cdot}$ ); 392.9+394.9 (ratio 1:1; 35; $\left[\mathrm{C}_{15} \mathrm{H}_{10} \mathrm{BrN}_{2} \mathrm{O}_{4} \mathrm{~S}\right]^{+}$); $380+381.9$ (ratio $1: 1 ; 68$; $\left[\mathrm{C}_{14} \mathrm{H}_{8} \mathrm{BrN}_{2} \mathrm{O}_{4} \mathrm{~S}\right]^{+\cdot}$ ); $300.0+302.0$ (ratio $1: 1 ; 100$; $\left.\left[\mathrm{C}_{14} \mathrm{H}_{7} \mathrm{BrNO}_{2}\right]^{+}\right) ; 221.1\left(40 ;\left[\mathrm{C}_{14} \mathrm{H}_{7} \mathrm{NO}_{2}\right]^{+}\right) ; 120.2$ (27; $\left[\mathrm{C}_{7} \mathrm{H}_{8} \mathrm{~N}\right]^{+}$). HRMS (70 eV, EI): Calcd.: 484.00924. Found: $484.0095 \Rightarrow \mathrm{C}_{22} \mathrm{H}_{17} \mathrm{BrN}_{2} \mathrm{O}_{4} \mathrm{~S}$. Anal. Calcd. for $\mathrm{C}_{22} \mathrm{H}_{17} \mathrm{BrN}_{2} \mathrm{O}_{4} \mathrm{~S} \cdot 0.5 \mathrm{H}_{2} \mathrm{O}: \mathrm{C}, 53.45 ; \mathrm{H}, 3.67 ; \mathrm{N}, 5.67$. Found: C, 53.50; H, 3.74; N, 5.56.

\section{Bis-(1-amino-4-bromoanthraquinone-2-sulfonic acid) 4-ethoxyphenylamide (34)}

The compound was prepared from $1.0 \mathrm{~g}(2.5 \mathrm{mmol})$ of $\mathbf{1 0}$ in $80 \mathrm{ml}$ of dichloromethane, and $1.0 \mathrm{ml}(1.05 \mathrm{~g}, 7.7 \mathrm{mmol})$ of 4-ethoxyaniline and $3 \mathrm{ml}$ of triethylamine in $10 \mathrm{ml}$ of dichloromethane. Reaction time: $16 \mathrm{~h}$ at RT; purification by column chromatography with dichloromethane:cyclohexane $(7: 3)$ as eluent. Upon concentrating the productcontaining fractions under reduced pressure the product precipitated and was filtered off.

Yield: $180 \mathrm{mg}(17 \%)$; mp $262^{\circ} \mathrm{C} .{ }^{1} \mathrm{H}-\mathrm{NMR}$ (DMSO- $d_{6}$ : $\mathrm{CDCl}_{3}$ (approx. 3:1)), $\left.500 \mathrm{MHz}, 303 \mathrm{~K}\right): \delta(\mathrm{ppm})=1.34(\mathrm{t}$, $\left.3 \mathrm{H},{ }^{3} J=7.0 \mathrm{~Hz}, \mathrm{CH}_{3}\right) ; 4.07\left(\mathrm{~d}, 2 \mathrm{H},{ }^{3} J=7.0 \mathrm{~Hz}, \mathrm{OCH}_{2}\right) ; 6.93$ $\left(\mathrm{dm}, 2 \mathrm{H},{ }^{3} J=8.9 \mathrm{~Hz}, \mathrm{C} 2^{\prime} \mathrm{H}, \mathrm{C} 6^{\prime} \mathrm{H}\right.$ or $\left.\mathrm{C}^{\prime} \mathrm{H}, \mathrm{C} 5^{\prime} \mathrm{H}\right) ; 7.19$ $\left(\mathrm{dm}, 2 \mathrm{H},{ }^{3} J=8.9 \mathrm{~Hz}, \mathrm{C} 2^{\prime} \mathrm{H}, \mathrm{C}^{\prime} \mathrm{H}\right.$ or $\left.\mathrm{C}^{\prime} \mathrm{H}, \mathrm{C} 5^{\prime} \mathrm{H}\right) ; 7.84(\mathrm{td}$, $2 \mathrm{H},{ }^{3} J=6.4 \mathrm{~Hz},{ }^{4} J=2.1 \mathrm{~Hz}, \mathrm{C} 6 \mathrm{H}, \mathrm{C} 6{ }^{\prime \prime} \mathrm{H}$ or $\left.\mathrm{C} 7 \mathrm{H}, \mathrm{C} 7 " \mathrm{H}\right)$; $7.86\left(\mathrm{td}, 2 \mathrm{H},{ }^{3} \mathrm{~J}=6.4 \mathrm{~Hz},{ }^{4} J=2.1 \mathrm{~Hz}, \mathrm{C} 6 \mathrm{H}, \mathrm{C} 6 " \mathrm{H}\right.$ or $\mathrm{C} 7 \mathrm{H}$, C7"H); 8.01 (s, 2H, C3H, C3"H); $8.04-8.08$ (m, 2H, C5H, $\mathrm{C}^{\prime \prime} \mathrm{H}$ or $\left.\mathrm{C} 8 \mathrm{H}, \mathrm{C} 8{ }^{\prime \prime} \mathrm{H}\right) ; 8.09-8.13(\mathrm{~m}, 2 \mathrm{H}, \mathrm{C} 5 \mathrm{H}, \mathrm{C} 5 " \mathrm{H}$ or $\left.\mathrm{C} 8 \mathrm{H}, \mathrm{C} 8{ }^{\prime \prime} \mathrm{H}\right) ; 8.25$ (br, 4H, 1-NH, $\left.1{ }^{1 "}-\mathrm{NH}_{2}\right) .{ }^{13} \mathrm{C}-\mathrm{NMR}$ (DMSO- $d_{6}: \mathrm{CDCl}_{3}$ (ca. 3:1)), $\left.125 \mathrm{MHz}, 303 \mathrm{~K}\right): \delta(\mathrm{ppm})=$ $14.04\left(\mathrm{CH}_{3}\right) ; 63.54\left(\mathrm{OCH}_{2}\right) ; 104.23(2 \mathrm{C}, \mathrm{C} 9 \mathrm{a}, \mathrm{C} 9 \mathrm{a})$; $115.42\left(2 \mathrm{C}, \mathrm{C} 3^{\prime}, \mathrm{C} 5^{\prime}\right) ; 117.63\left(2 \mathrm{C}, \mathrm{C} 4 \mathrm{a}, \mathrm{C} 4 \mathrm{a}^{\prime \prime}\right) ; 123.15$ (C1'); 124.00 (2C, C4, C4"); 126.03, 126.20 (2C each, C5, C5", C8, C8"); 132.48 (C8a, C8a" or C10a, C10a"); 132.76 (2C, $\left.\mathrm{C} 2^{\prime}, \mathrm{C6}^{\prime}\right) ; 132.85$ (C8a, C8a" or C10a, C10a"); 133.87, 134.10 (2C each, C6, C6", C7, C7"); 136.74 (2C, C2, C2"); 143.03 (2C, C3, C3"); 147.82 (2C, C1, C1"); 160.46 (C4'); 181.26, 183.71 (2C each, C9, C9", C10, C10"). EI-MS: $\mathrm{m} / \mathrm{z}(\%)=867.0+865+863$ (ratio $1: 2: 1 ; 11$; $\left[\mathrm{C}_{36} \mathrm{H}_{23} \mathrm{Br}_{2} \mathrm{~N}_{3} \mathrm{O}_{9} \mathrm{~S}\right]^{+}$); $500+502.0$ (ratio 1:1; 34; $\left[\mathrm{C}_{22} \mathrm{H}_{17} \mathrm{BrN}_{2} \mathrm{O}_{5} \mathrm{~S}\right]^{+\cdot}$ ); 301.0+303 (ratio 1:1; 25; $\left.\left[\mathrm{C}_{14} \mathrm{H}_{8} \mathrm{BrNO}_{2}\right]^{+}\right) ; 136.1\left(100 ;\left[\mathrm{C}_{8} \mathrm{H}_{10} \mathrm{NO}\right]^{+}\right) ; 108.1(69$; $\left.\left[\mathrm{C}_{6} \mathrm{H}_{6} \mathrm{NO}\right]^{+}\right)$. IR $(\mathrm{KBr}): v\left[\mathrm{~cm}^{-1}\right]=3459,3420\left(\mathrm{NH}_{2}\right) ; 1669$ $(\mathrm{C}=\mathrm{O}) ; 1587(\mathrm{Ar}) ; 1499(\mathrm{Ar}) ; 1390,1366\left(\mathrm{SO}_{2} \mathrm{NR}_{2}\right) ; 1254$ (C-O); $1160\left(\mathrm{SO}_{2} \mathrm{NR}_{2}\right) ; 889$ (Ar); 745, 724 (o-subst. Ar).

\section{Bis-(1-amino-4-bromoanthraquinone-2-sulfonic acid) 2-methoxyphenylamide (35)}

The compound was prepared from $1.0 \mathrm{~g}(2.5 \mathrm{mmol})$ of $\mathbf{1 0}$ in $80 \mathrm{ml}$ of dichloromethane, and $1.0 \mathrm{ml}(1.092 \mathrm{~g}$, $8.867 \mathrm{mmol}$ ) of 2-methoxyaniline and $3 \mathrm{ml}$ of triethylamine in $10 \mathrm{ml}$ of dichloromethane. Reaction time: $16 \mathrm{~h}$ at RT; purification by column chromatography with dichloromethane:cyclohexane (7:3) as eluent.

Yield: $180 \mathrm{mg}(14 \%) ; \mathrm{mp} 271{ }^{\circ} \mathrm{C} .{ }^{1} \mathrm{H}-\mathrm{NMR}$ (DMSO- $d_{6}$, $500 \mathrm{MHz}, 303 \mathrm{~K}): \delta(\mathrm{ppm})=3.60\left(\mathrm{~s}, 3 \mathrm{H}, \mathrm{CH}_{3}\right) ; 7.13(\mathrm{dd}$, $1 \mathrm{H},{ }^{3} J=8.4 \mathrm{~Hz},{ }^{4} J=1.3 \mathrm{~Hz}, \mathrm{C} 3^{\prime} \mathrm{H}$ or $\left.\mathrm{C}^{\prime} \mathrm{H}\right) ; 7.13$ (ddd, $1 \mathrm{H}$, ${ }^{3} J=8.0 \mathrm{~Hz},{ }^{3} J=7.6 \mathrm{~Hz},{ }^{4} J=0.7 \mathrm{~Hz}, \mathrm{C} 3{ }^{\prime} \mathrm{H}$ or $\left.\mathrm{C}^{\prime}{ }^{\prime} \mathrm{H}\right) ; 7.47$ $\left(\mathrm{dd}, 1 \mathrm{H},{ }^{3} J=8.2 \mathrm{~Hz},{ }^{4} J=1.6 \mathrm{~Hz}, \mathrm{C} 3^{\prime} \mathrm{H}\right.$ or $\left.\mathrm{C}^{\prime}{ }^{\prime} \mathrm{H}\right) ; 7.57$ (ddd, $1 \mathrm{H},{ }^{3} J=8.3 \mathrm{~Hz},{ }^{3} J=7.5 \mathrm{~Hz},{ }^{4} J=1.7 \mathrm{~Hz}, \mathrm{C} 3{ }^{\prime} \mathrm{H}$ or $\left.\mathrm{C} 4^{\prime} \mathrm{H}\right)$; 7.85 (td, $2 \mathrm{H},{ }^{3} J=7.2 \mathrm{~Hz},{ }^{4} \mathrm{~J}=1.7 \mathrm{~Hz}, \mathrm{C} 6 \mathrm{H}, \mathrm{C} 6 " \mathrm{H}$ or $\mathrm{C} 7 \mathrm{H}$, $\left.\mathrm{C} 7{ }^{\prime \prime} \mathrm{H}\right) ; 7.88\left(\mathrm{td}, 2 \mathrm{H},{ }^{3} \mathrm{~J}=7.2 \mathrm{~Hz},{ }^{4} \mathrm{~J}=1.8 \mathrm{~Hz}, \mathrm{C} 6 \mathrm{H}, \mathrm{C} 6{ }^{\prime \prime} \mathrm{H}\right.$ or $\mathrm{C} 7 \mathrm{H}, \mathrm{C} 7 " \mathrm{H}) ; 8.01$ (ddm, $2 \mathrm{H},{ }^{3} \mathrm{~J}=6.8 \mathrm{~Hz},{ }^{4} \mathrm{~J}=2.1 \mathrm{~Hz}, \mathrm{C} 5 \mathrm{H}$, $\mathrm{C} 5 " \mathrm{H}$ or $\mathrm{C} 8 \mathrm{H}, \mathrm{C} 8 " \mathrm{H}) ; 8.08\left(\mathrm{ddm}, 2 \mathrm{H},{ }^{3} \mathrm{~J}=6.4 \mathrm{~Hz},{ }^{4} \mathrm{~J}=\right.$ $2.5 \mathrm{~Hz}, \mathrm{C} 5 \mathrm{H}, \mathrm{C} 5{ }^{\prime \prime} \mathrm{H}$ or C8H, C8"H); 8.08 (s, 2H, C3H, C3" $\mathrm{H}) ; 8.35$ (br, $4 \mathrm{H}, 1-\mathrm{NH}_{2}, 1{ }^{1 "}-\mathrm{NH}_{2}$ ). ${ }^{13} \mathrm{C}-\mathrm{NMR}$ (DMSO- $d_{6}$, $125 \mathrm{MHz}, 303 \mathrm{~K}): \delta(\mathrm{ppm})=55.53\left(\mathrm{OCH}_{3}\right) ; 103.84(2 \mathrm{C}$, 
C9a, C9a"); 112.80 (C3'); 117.18 (2C, C4a, C4a"); 119.42 , 121.15 (C1', C5'); 124.15 (2C, C4, C4"); 126.05, 126.20 (2C each, C5, C5", C8, C8"); 132.45, 132.86, 132.99, 133.19 (C8a, C8a", C10a, C10a", C4', C6'); 134.08, 134.35 (2C each, C6, C6", C7, C7"); 136.75 (2C, C2, C2"); 143.18 (2C, C3, C3"); 148.13 (2C, C1, C1"); 157.11 (C4'); 181.34, 183.66 (2C each, C9, C9", C10, C10"). EI-MS: m/z (\%)= 848.9+850.9+853 (ratio 1:2: $1 ; 27 ;\left[\mathrm{C}_{35} \mathrm{H}_{21} \mathrm{Br}_{2} \mathrm{~N}_{3} \mathrm{O}_{9} \mathrm{~S}\right]^{+}$); $486+488.0$ (ratio 1:1; 80; $\left[\mathrm{C}_{21} \mathrm{H}_{15} \mathrm{BrN}_{2} \mathrm{O}_{5} \mathrm{~S}\right]^{+-}$); $301.0+303$ (ratio 1:1; 34; $\left.\left[\mathrm{C}_{14} \mathrm{H}_{8} \mathrm{BrNO}_{2}\right]^{+}\right) ; 122.1\left(100 ;\left[\mathrm{C}_{7} \mathrm{H}_{8} \mathrm{NO}\right]^{+}\right)$. IR $(\mathrm{KBr}): \vee\left[\mathrm{cm}^{-1}\right]=3424\left(\mathrm{NH}_{2}\right) ; 2845\left(\mathrm{OCH}_{3}\right) ; 1675(\mathrm{C}=$ O); 1594 (Ar); $1366\left(\mathrm{SO}_{2} \mathrm{NR}_{2}\right) ; 1257$ (CO); 11.78 $\left(\mathrm{SO}_{2} \mathrm{NR}_{2}\right) ; 891$ (Ar); 724 (o-subst. Ar).

\section{NTPDase inhibition assays}

\section{Enzyme preparations}

The preparation of recombinant rat NTPDase1-3 was performed essentially as described by Iqbal et al. [27]. In brief, Chinese hamster ovary (CHO) cells were transfected by electroporation with plasmid DNA-containing rat NTPDase1 (GenBank Accession number U81295) [51] and NTPDase2 (Y11835) [51] and NTPDase3 (AJ437217) [52], all cloned into the pcDNA3 plasmid. Transfection with the empty plasmid pcDNA3 served as a control. Membrane fractions were prepared in the presence of protease inhibitors from transiently transfected $\mathrm{CHO}$ cells $48 \mathrm{~h}$ after electroporation. The final pellet fraction was resuspended in $50 \%$ $(\mathrm{v} / \mathrm{v})$ glycerol containing $2 \mathrm{mM}$ iodoacetamide, $20 \mathrm{mM}$ HEPES (pH 7.4) and stored at $-20^{\circ} \mathrm{C}$. The membrane preparations contained $4-6 \mu \mathrm{g}$ of protein $/ \mu \mathrm{l}$.

\section{Enzyme assay}

Stock solutions (10 mM or $1 \mathrm{mM})$ of test compounds were prepared in water or water containing $10 \%$ DMSO for the more lipophilic compounds, respectively, and dilutions were made in assay buffer $(140 \mathrm{mM} \mathrm{NaCl}, 5 \mathrm{mM} \mathrm{KCl}$, $1 \mathrm{mM} \mathrm{MgCl} 2,2 \mathrm{mM} \mathrm{CaCl}_{2}, 10 \mathrm{mM}$ HEPES, $\mathrm{pH}$ 7.4). The reaction mixture for NTPDase inhibition assays contained ATP (final concentration $400 \mu \mathrm{M}$ ) dissolved in assay buffer and test compound (10 $\mu \mathrm{l}$, different concentrations). The reaction was started by the addition of $10 \mu \mathrm{l}$ of enzymecontaining membrane preparation to obtain a final volume of $100 \mu \mathrm{l}$. Control experiments were performed using membrane preparations of cells transfected with the empty plasmid (pcDNA3). The reaction was carried out at $37^{\circ} \mathrm{C}$ for $10 \mathrm{~min}$ and stopped by heating at $99^{\circ} \mathrm{C}$ for $3 \mathrm{~min}$. Then $50 \mu \mathrm{l}$ were transferred to a CE vial and mixed with an UMP solution (final concentration $10 \mu \mathrm{M}$, internal standard) in $450 \mu \mathrm{l}$ of water. The resulting solution was subjected to CE analysis using a P/ACE MDQ CE system (Beckman Instruments, Fullerton, CA, USA) equipped with a UV detection system coupled with a diode array detector. The capillary temperature was kept constant at $25^{\circ} \mathrm{C}$. The temperature of the sample storing unit was adjusted to $25^{\circ} \mathrm{C}$. The electrophoretic separations were carried out using an eCAP polyacrylamide-coated fused-silica capillary [30 $\mathrm{cm}(20 \mathrm{~cm}$ effective length $) \times 50 \mu \mathrm{m}$ internal diameter $\times$ $360 \mu \mathrm{m}$ outer diameter, obtained from CS-Chromatographie (Langerwehe, Germany)]. The separations were performed with phosphate buffer $50 \mathrm{mM}, \mathrm{pH} 6.5$ using an applied current of $-60 \mu \mathrm{A}$ and a data acquisition rate of $8 \mathrm{~Hz}$. Analytes were detected using direct UV absorbance at $210 \mathrm{~nm}$. The capillary was conditioned by rinsing with water for 2 min and subsequently with phosphate buffer for $1 \mathrm{~min}$. Sample injections were made at the cathodic side of the capillary. Data collection and peak area analysis were performed by the P/ACE MDQ software 32 KARAT. Inhibition curves were analyzed by Prism 3.0 (GraphPad, San Diego, CA, USA).

\section{References}

1. Burnstock G (2007) Physiology and pathophysiology of purinergic neurotransmission. Physiol Rev 87:659-797

2. Zimmermann H (1999) Two novel families of ectonucleotidases: molecular structures, catalytic properties and a search for function. Trends Pharmacol Sci 20:231-236

3. Borsellino G, Kleinewietfeld M, Di Mitri D, Sternjak A, Diamantini A, Giometto R, Höpner S, Centonze D, Bernardi G, Dell'Acqua ML, Rossini PM, Battistini L, Rötzsche O, Falk K (2007) Expression of ectonucleotidase CD39 by Foxp3+ Treg cells: hydrolysis of extracellular ATP and immune suppression. Blood 110:1225-1235

4. Zimmermann H (2000) Extracellular metabolism of ATP and other nucleotides. Naunyn Schmiedebergs Arch Pharmacol 362:299-309

5. Zimmermann H (2006) Ectonucleotidases in the nervous system. Novartis Found Symp 276:113-128

6. Zimmermann H (2001) Ectonucleotidases: some recent developments and a note on nomenclature. Drug Devt Res 52:44-56

7. Knowles AF, Li C (2006) Molecular cloning and characterization of expressed human ectonucleoside triphosphate diphosphohydrolase 8 (E-NTPDase8) and its soluble extracellular domain. Biochemistry 45:7323-7333

8. Fausther M, Lecka J, Kukulski F, Lévesque SA, Pelletier J, Zimmermann H, Dranoff JA, Sévigny J (2007) Cloning, purification, and identification of the liver canalicular ecto-ATPase as NTPDase8. Am J Physiol Gastrointest Liver Physiol 292:G785G795

9. Mulero JJ, Yeung G, Nelken ST, Ford JE (1999) CD39-L4 is a secreted human apyrase, specific for the hydrolysis of nucleoside diphosphates. J Biol Chem 274:20064-20067

10. Kukulski F, Komoszynski M (2003) Purification and characterization of NTPDase1 (ecto-apyrase) and NTPDase2 (ecto-ATPase) from porcine brain cortex synaptosomes. Eur J Biochem 270:3447-3454

11. Heine P, Braun N, Sevigny J, Robson SC, Servos J, Zimmermann H (2001) The C-terminal cysteine-rich region dictates specific 
catalytic properties in chimeras of the ectonucleotidases NTPDase1 and NTPDase2. Eur J Biochem 268:364-373

12. Kirley TL, Crawford PA, Smith TM (2006) The structure of the nucleoside triphosphate diphosphydrolases (NTPDases) as revealed by mutagenic and computational modelin analyses. Purinergic Signalling 2:379-389

13. Heine P, Braun N, Heilbronn A, Zimmermann H (1999) Functional characterization of rat ecto-ATPase and ecto-ATP diphosphohydrolase after heterologous expression in $\mathrm{CHO}$ cells. Eur J Biochem 262:102-107

14. Failer BU, Aschrafi A, Schmalzing G, Zimmermann H (2003) Determination of native oligomeric state and substrate specificity of rat NTPDase1 and NTPDase2 after heterologous expression in Xenopus oocytes. Eur J Biochem 270:1802-1809

15. Robson SC, Sévigny J, Zimmermann H (2006) The E-NTPDase family of ectonucleotidases: structure-function relationships and pathophysiological significance. Purinergic Signalling 2:409430

16. Sévigny J, Sundberg C, Braun N, Guckelberger O, Csizmadia E, Qawi I, Imai M, Zimmermann H, Robson SC (2002) Differential catalytic properties and vascular topography of murine nucleoside triphosphate diphosphohydrolase 1 (NTPDase1) and NTPDase2 have implications for thromboregulation. Blood 99:801-2809

17. Wink MR, Braganhol E, Tamajusuku ASK, Lenz G, Zerbini LF, Libermann TA, Sévigny J, Battastini AMO, Robson SC (2006) Nucleoside triphosphate diphosphohydrolase-2 (NTPDase2/ CD39L1) is the dominant ectonucleotidase expressed by rat astrocytes. Neuroscience 138:421-432

18. Langer D, Ikehara Y, Takebayashi H, Hawkes R, Zimmermann H (2007) The ectonucleotidases alkaline phosphatase and nucleoside triphosphate diphosphohydrolase 2 are associated with subsets of progenitor cell populations in the mouse embryonic, postnatal and adult neurogenic zones. Neuroscience 150:863-879

19. Knowles AF, Chiang W-C (2003) Enzymatic and transcriptional regulation of human ecto-ATPase/E-NTPDase 2. Arch Biochem Biophys 418:217-227

20. Buffon A, Ribeiro VB, Wink MR, Casali EA, Sarkis JJ (2007) Nucleotide metabolizing ecto-enzymes in Walker 256 tumor cells: molecular identification, kinetic characterization and biochemical properties. Life Sci 80:950-958

21. Belcher SM, Zsarnovszky A, Crawford PA, Hemani H, Spurling L, Kirley TL (2006) Immunolocalization of ecto-nucleoside triphosphate for modulation of multiple homeostatic systems including feeding and sleep-wake behaviours. Neuroscience 137:1331-1346

22. Vlajkovic SM, Vinayagamoorthy A, Thorne PR, Robson SC, Wang CJ, Housley GD (2006) Noise-induced up-regulation of NTPDase 3 expression in the rat cochlea: implications for auditory transmission and cochlear protection. Brain Res 1104:55-63

23. Gendron FP, Benrezzak O, Krugh BW, Kong Q, Weisman GA, Beaudoin AR (2002) Purine signaling and potential new therapeutic approach: possible outcomes of NTPDase inhibition. Curr Drug Targets 3:229-245

24. Kennedy C, Westfall TD, Sneddon P (1996) Modulation of purinergic neurotransmission by ecto-ATPase. Semin Neurosci 8:195-199

25. Dowd FJ, Li LS, Zeng W (1999) Inhibition of rat parotid ectoATPase activity. Arch Oral Biol 44:1055-1062

26. Drakulich DA, Spellmon C, Hexum TD (2004) Effect of the ectoATPase inhibitor, ARL 67156, on the bovine chromaffin cell response to ATP. Eur J Pharmacol 485:137-140

27. Iqbal J, Vollmayer P, Braun N, Zimmermann H, Müller CE (2005) A capillary electrophoresis method for the characterization of ecto-nucleoside triphosphate diphosphohydrolases (NTPDases) and the analysis of inhibitors by in-capillary enzymatic microreaction. Purinergic Signalling 1:349-358
28. Lévesque SA, Lavoie EG, Lecka J, Bigonnesse F, Sévigny J (2007) Specificity of the ecto-ATPase inhibitor ARL 67156 on human and mouse ectonucleotidases. Br J Pharmacol 152:141150

29. Gendron FP, Halbfinger E, Fischer B, Duval M, D’Orléans-Juste P, Beaudoin AR (2000) Novel inhibitors of nucleoside triphosphate diphosphohydrolases: chemical synthesis and biochemical and pharmacological characterizations. J Med Chem 43:22392247

30. Brunschweiger A, Iqbal J, Umbach F, Scheiff AB, Munkonda MN, Sévigny J, Knowles AF, Müller CE (2008) Selective nucleoside triphosphate diphosphohydrolase-2 (NTPDase2) inhibitors: nucleotide mimetics derived from uridine-5'-carboxamide. J Med Chem, in press

31. Demenis MA, Furriel RP, Leone FA (2003) Characterization of an ectonucleoside triphosphate diphosphohydrolase 1 activity in alkaline phosphatase-depleted rat osseous membranes: possible functional involvement in the calcification process. Biochem Biophys Acta 1646:216-225

32. Crack BE, Beukers MW, McKechnie KC, Ijzerman AP, Leff $P$ (1994) Pharmacological analysis of ecto-ATPase inhibition: evidence for combined enzyme inhibition and receptor antagonism in P2X-purinoceptor ligands. Br J Pharmacol 113:1432-1438

33. Bültmann R, Wittenburg H, Pause B, Kurz G, Nickel P, Starke K (1996) P2-purinoceptor antagonists: III. Blockade of P2-purinoceptor subtypes and ecto-nucleotidases by compounds related to suramin. Naunyn Schmiedebergs Arch Pharmacol 354:498-504

34. Wittenburg H, Bültmann R, Pause B, Ganter C, Kurz G, Starke K (1996) P2-purinoceptor antagonists: II. Blockade of P2-purinoceptor subtypes and ecto-nucleotidases by compounds related to Evans blue and trypan blue. Naunyn Schmiedebergs Arch Pharmacol 354:491497

35. Stout JG, Kirley TL (1995) Inhibition of purified chicken gizzard smooth muscle ecto-ATPase by P2 purinoceptor antagonists. Biochem Mol Biol Int 36:927-934

36. Bültmann R, Starke K (1995) Reactive red 2: a P2y-selective purinoceptor antagonist and an inhibitor of ecto-nucleotidase. Naunyn Schmiedebergs Arch Pharmacol 352:477-482

37. Tuluc F, Bültmann R, Glänzel M, Frahm AW, Starke K (1998) P2receptor antagonists: IV. Blockade of P2-receptor subtypes and ecto-nucleotidases by compounds related to reactive blue 2 . Naunyn Schmiedebergs Arch Pharmacol 357:111-120

38. Hoffmann C, Heine P, Pradel G, Kim YC, Jacobson KA, Zimmermann H (2000) Inhibition of ecto-apyrase and ectoATPase by pyridoxal phosphate-related compounds. Drug Dev Res 51:153-158

39. Chen BC, Lee CM, Lin WW (1996) Inhibition of ecto-ATPase by PPADS, suramin and reactive blue in endothelial cells, C6 glioma cells and RAW 264.7 macrophages. Br J Pharmacol 119:1628-1634

40. Müller CE, Iqbal J, Baqi Y, Zimmermann H, Röllich A, Stephan H (2006) Polyoxometalates - a new class of potent ecto-nucleoside triphosphate diphosphohydrolase (NTPDase) inhibitors. Bioorg Med Chem Lett 16:5943-5947

41. Köhler C, Eckle T, Faigle M, Grenz A, Mittelbronn M, Laucher S, Hart ML, Robson SC, Müller CE, Eltzschig HK (2007) CD39/ ectonucleoside triphosphate diphosphohydrolase 1 provides myocardial protection during cardiac ischemia/reperfusion injury. Circulation 116:1784-1794

42. Grenz A, Zhang H, Hermes M, Eckle T, Klingel K, Huang DY, Müller CE, Robson SC, Osswald H, Eltzschig HK (2007) Contribution of E-NTPDase1 (CD39) to renal protection from ischemia-reperfusion injury. FASEB J 21:2863-2873

43. Coppi E, Pugliese AM, Stephan H, Müller CE, Pedata F (2007) Role of P2 purinergic receptors in synaptic transmission under normoxic and ischaemic conditions in the CA1 region of rat hippocampal slices. Purinergic Signalling 3:203-219 
44. Munkonda MN, Kauffenstein G, Kukulski F, Lévesque SA, Legendre C, Pelletier J, Lavoie EG, Lecka J, Sévigny J (2007) Inhibition of human and mouse plasma membrane bound NTPDases by P2 receptor antagonists. Biochem Pharmacol 74:1524-1534

45. Weyler S, Baqi Y, Hillmann P, Kaulich M, Hunder AM, Müller IA, Müller CE (2008) Combinatorial synthesis of anilinoanthraquinone derivatives and evaluation as non-nucleotidederived $\mathrm{P}_{2} \mathrm{Y}_{2}$ receptor antagonists. Bioorg Med Chem Lett 18:223-227

46. Baqi Y, Müller CE (2007) Rapid and efficient microwave-assisted copper(0)-catalyzed Ullmann coupling reaction. Org Lett 9:12711274

47. Harris RM, Mariott GJ, Smith JC (1936) The effect of alkyl groups on the properties of anthraquinone and fluorescein dyes. J Chem Soc 1838-1842. DOI 10.1039/JR9360001838
48. Glänzel M, Bültmann R, Starke K, Frahm AW (2003) Members of the acid blue 129 family as potent and selective P2Y-receptor antagonists. Drug Dev Res 59:63-71

49. Bessubetz MK, Rozina VS (1948) Acidic derivatives of anthraquinone. I. Influence of substituents in the phenylamine radical of anthraquinone derivatives on their properties. Zh Prikl Khim 21:1152-1161

50. I.G. Farbenindustrie AG (1933) Anthraquinone derivatives. French Patent FR 75123619330829

51. Kegel B, Braun N, Heine P, Maliszewski CR, Zimmermann H (1997) An ecto-ATPase and an ecto-ATP diphosphohydrolase are expressed in rat brain. Neuropharmacology 36:1189-1200

52. Vorhoff T, Zimmermann H, Pelletier J, Sévigny J, Braun N (2005) Cloning and characterization of the ecto-nucleotidase NTPDase3 from rat brain: predicted secondary structure and relation to other members of the E-NTPDase family and actin. Purinergic Signalling 1:259-270 